\title{
EL THRILLER MEDIÁTICO DEL ASESINATO DE JAIME GARZÓN
}

\section{James Cortés-Tique}

Doctor en Estudios Ibéricos e iberoamericanos Universidad Michel de Montaigne, Bordeux III

Profesor de la Escuela de Estudios Literarios

Universidad del Valle

\section{Resumen:}

Este artículo estudiamos la movilidad cognitiva y pasional de la prensa colombiana durante el cubrimiento de la noticia del asesinato y del funeral del humorista Jaime Garzón. Tal movilidad será analizada a través de la observación de los efectos de género -o modelización genérica- que se suceden durante la construcción del macro-relato mediático agenciado por periodistas de radio, televisión, prensa escrita en revistas y periódicos. El enfoque propuesto permite mostrar, de la mano de la modelización genérica, la labilidad ética de la prensa colombiana.

\section{Palabras Claves:}

Semiótica, teoría de géneros, Jaime Garzón. 


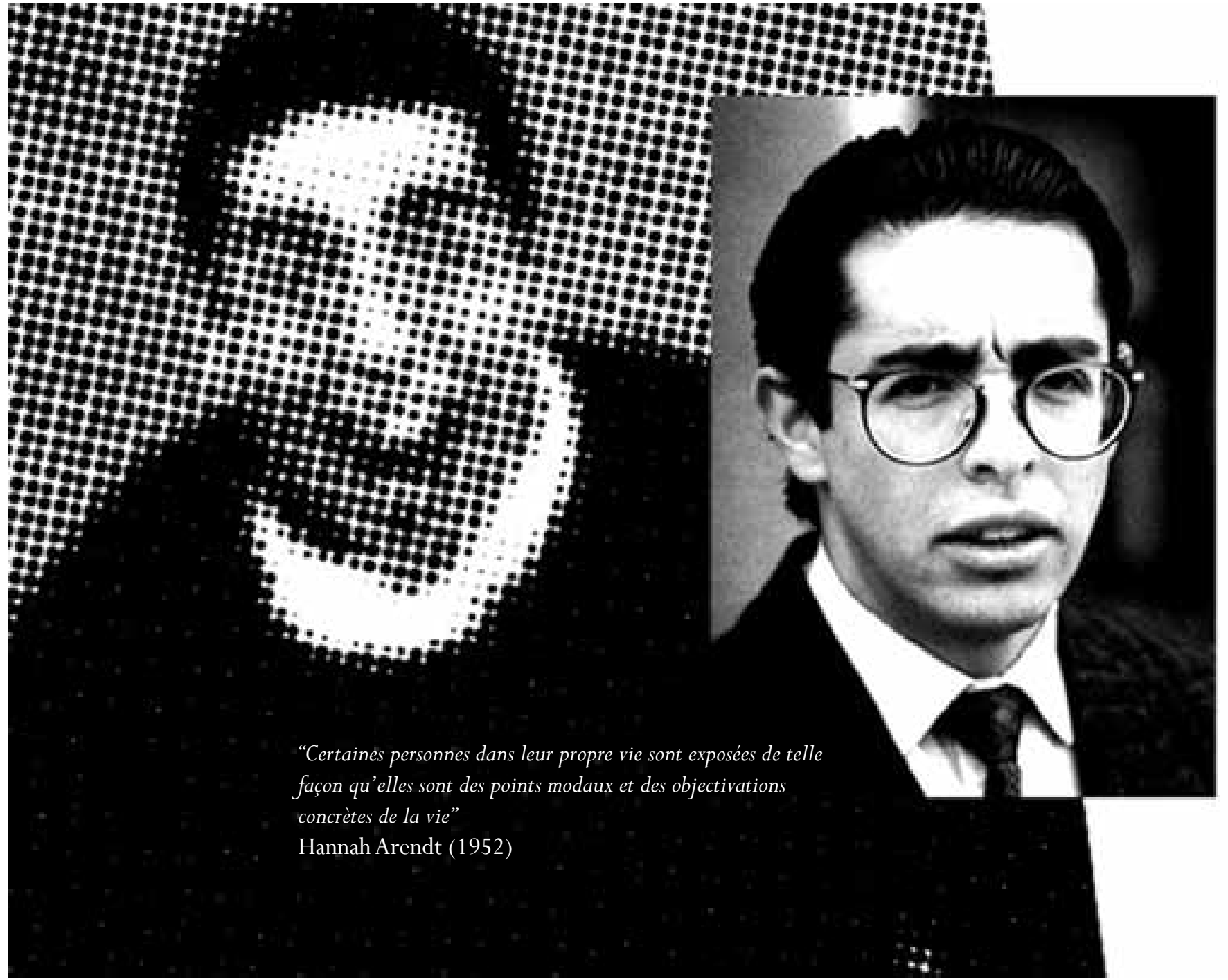

\section{Introducción}

En este artículo rendimos homenaje al hombre que, gracias a su talento, dio lugar a la creación del meta-periodismo en Colombia, a través de los programas Zoociedad (1990-1993), Quac el noticero (1995-1997) y del personaje Heriberto de la Calle (1997-1999). La propuesta más sistemática del meta-periodismo la encontramos en Quac el noticero, programa que, desde la ironía burlesca, parodió los noticieros de televisión colombianos y puso en evidencia la ficción-seria que subyace en los macrorelatos mediáticos ${ }^{1}$ (lo cual fue particularmente evidente con el Proceso 8.000, escándalo que fue escenificado por y para los medios de comunicación y que tuvo efectos de género propios del thriller periodístico ${ }^{2}$ ). Lo anterior nos sirve para presentar la idea que subyace en la concepción de este artículo: Jaime Garzón no pudo escapar a los efectos ficcionales de la narrativización periodística que él mismo denunciara en Quac el noticero; una vez asesinado fue objeto de la construcción de un thriller periodístico con efectos de novela negra ${ }^{3}$. 


\section{Acting out: de las pantallas a la realidad}

Después de Quac el noticero, Jaime Garzón se embarcó con su socio creativo, Antonio Morales, en otro programa, Lechuza (1997), en el que nació el personaje Heriberto de la Calle. Este personaje acumula el capital simbólico de las emisiones anteriores y condensa la poética de la ironía en la parodia burlesca. Heriberto de la Calle es el nombre del concepto comprado por CM\&, luego por Caracol Televisión (con participación en RadioNet). Este es el personaje que los telespectadores guardan en la memoria inmediata en el momento del crimen.

De manera paralela, en desarrollo de otras actividades ajenas a su rol de humorista, Jaime Garzón asume, durante este periodo, diversos compromisos ciudadanos: participa en las mesas de diálogos de paz con el Ejército de Liberación Nacional (ELN), sirve de mediador en la liberación de secuestrados y da entrevistas para diferentes medios de comunicación y conferencias donde lo llamen. La palabra lúdica del humorista se encabalga con la palabra seria del ciudadano cuando se trata de denunciar los excesos de poder. En estos momentos el bufón está fuera de escena, fuera de la ficción, es un cualquiera, un ciudadano inerme actuando en el marco de lo serio, de lo que causa efectos en la realidad. Los psicólogos bien podrían hablar de un acting out, un paso a la locura. Dicho en términos figurativos, Jaime Garzón se sale del campo de los fuegos de artificio, la ficción, para entrar en un verdadero campo minado, la realidad.

\section{Un thriller con efectos de novela negra}

De varios periódicos y revistas resumimos el siguiente pasaje narrativo: eran aproximadamente las 5:45 de la mañana del viernes 13 de agosto de 1999 cuando dos sicarios en una motocicleta lo interceptan. Uno dispara contra el conductor de una camioneta Cherokee verde. Cinco tiros dan en el blanco. La camioneta sigue con el mínimo impulso, sin control, casi una cuadra, hasta estrellarse contra un poste del alumbrado eléctrico. $\mathrm{Al}$ conductor sólo le faltaban pocas cuadras para llegar a RadioNet (en cursiva), su sitio de trabajo. Un cuarto de hora después, a las 6:01, la jefe de redacción de la cadena de noticias RadioNet, Aída Luz Herrera, inicia el cubrimiento del acontecimiento diciendo que "no se escucharían más las voces y las risas de Heriberto porque lo habían asesinado" (El Tiempo, 14/08/1999).
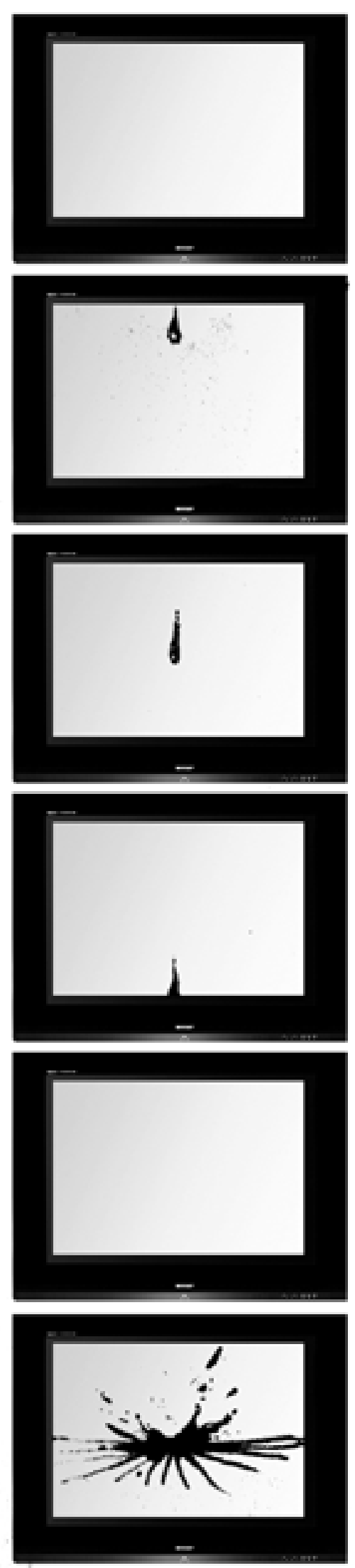
Ahora bien, que la periodista confunda a Heriberto de la Calle, el nombre del personaje de ficción, con Jaime Hernando Garzón Forero es, en términos ontológicos, una con-fusión de lo real y de lo ficcional, pero no un equívoco pues, en términos pragmáticos, se trata de un acierto. Es compresible que los radioescuchas tengan más signos de reconocimiento con el personaje ficcional, que con el comediante que le da vida. El personaje: alguien con oficio de lustrador de zapatos, cuyos rasgos particulares son: una cincuentena de años, gracias al maquillaje; totalmente mueco, salvo un colmillo; indiscreto e irreverente, a tal punto que en términos del argot colombiano se le podría llamar un igualado. Del otro, del comediante Jaime Hernando Garzón Forero, en ese momento no se sabe mucho, excepto que gracias a su talento histriónico de imitador y creador de voces había alcanzado el estatus de periodista y de humorista. El personaje bien podía haber sido víctima de una de las tantas "limpiezas sociales", el periodista y humorista, supuestamente, no.

Por otra parte, cabe señalar algunos aspectos que configuran la naturaleza singular de la que se convertirá en la noticia del día: que el acontecimiento ocurra cerca de la sede de un noticiero es, para los periodistas de RadioNet, como si la primicia les cayera del cielo; además, que el muerto sea un periodista, hace que la noticia se convierta en un acontecimiento que implica al gremio: el periodismo entero es concernido, tanto más cuanto que se trata de una celebridad. Se desenvuelve entonces la bandera de la libertad de prensa que antes había sido enarbolada con el asesinato de don Guillermo Cano, en 1987, y luego, durante los secuestros de periodistas-políticos ordenados por Pablo Escobar, en 1990 (entre los cuales la prensa sólo destacó dos nombres, el de Francisco Santos y el de Diana Turbay), pero esta vez la bandera es enarbolada con más pasión.

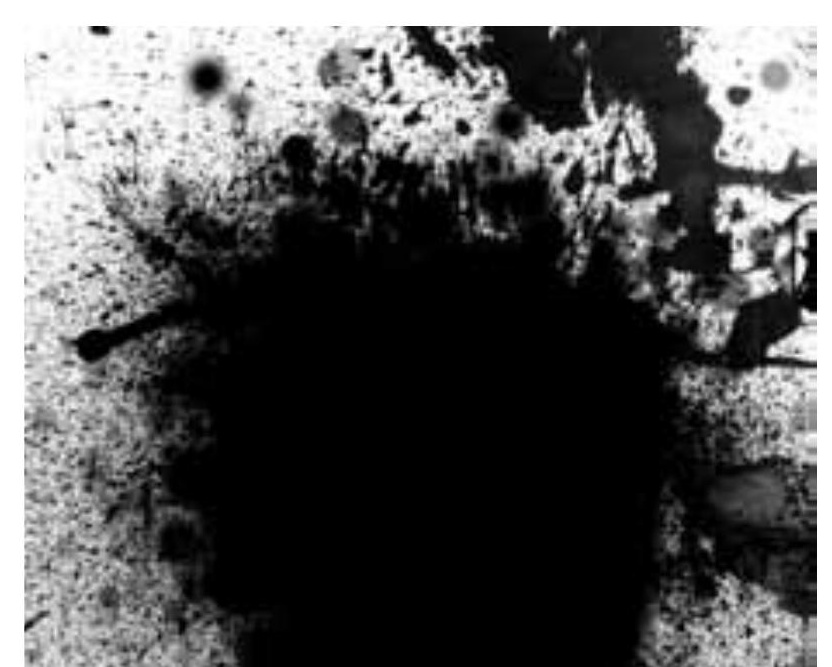

\section{Apuntes sobre el relato telenovelesco}

En cuanto a la sintaxis gloabal, algunas características del macro-relato mediático o telenovelesco son las siguientes:

\footnotetext{
Es un relato cuya intriga se escribe progresivamente, en la ignorancia provisional del desencadenamiento. Es un relato partido, que avanza por pedazos, que se construye en el momento a momento, prácticamente en tiempo real: es el desarrollo efectivo de los acontecimientos el que dicta su ritmo temporal. Es un relato abierto en el que el narrador (el periodista) no domina ni la importancia, ni la duración, ni el alcance. Es en gran parte prospectivo y la intriga puede proliferar al ser exploradas las diferentes vías posibles. (Françoise Revaz, 2009: 192. La traducción es nuestra).
}

Estas características súper-estructurales son válidas para relatar un partido de fútbol, un reinado de belleza, los escándalos de corrupción, las elecciones presidenciales... La lista es larga. Al tratarse del asesinato de personalidades, de secuestros y de atentados terroristas, el relato telenovelesco suele adquirir matices semánticos propios del género thriller (aleccionante, moralizante, legitimante) y no de novela negra contemporánea que, en tanto que "modo de la sospecha generalizada", no acepta lo real más que a beneficio de inventario y, por lo tanto, está axiológicamente comprometida con la denuncia del sistema, del statu quo, del establecimiento ${ }^{5}$, de manera tal que puede decirse, con Hannah Arendt, que se encuentra especialmente interesada en la "banalidad del mal".

El establecimiento de esta diferencia entre el estatuto del thriller y el de la novela negra permite identificar una singularidad de primera importancia en el modo en que se narrativizó el asesinato de Jaime Garzón: en el seno del thriller construido por el conjunto de la prensa colombiana, van a aparecer algunos efectos, matices, visos, de novela negra -en el sentido axiológico de Jean Pons- que nos interesa señalar, y que constituyen una ruptura en la historia reciente del periodismo colombiano. 
Siguiendo a Todorov (1971), podemos afirmar que el macro-relato telenovelesco de la muerte de Jaime Garzón, privilegió la relación que va de los efectos a las causas: a partir de un cierto efecto (el crimen y ciertos indicios), es preciso encontrar la causa (el culpable y el móvil del crimen). Pero esta generalización necesita de otras precisiones como la diferencia entre el detective y el narrador. Estos dos roles cognitivos no se confunden. El detective tiene la función de apropiarse de información; el narrador, la de proveerla al narratario. El día del crimen de Garzón, los periodistas (narradores) informan sobre lo que ocurre, en directo, desde el lugar de los acontecimientos. ¿Pero, qué observan? A los detectives, que están representados por los organismos de inteligencia de la Policía Judicial, siendo ellos los que tienen acceso directo al "cuerpo del delito", a "la escena del crimen" y a los aspectos relacionados con las pesquisas de la investigación. Toda la información judicial es clasificada, confidencial, reservada. La prensa, instancia narratorial, es la última de la cola en la jerarquía de acceso a dicho tipo de información (en realidad los últimos somos los telespectadores). ¿De dónde entonces la función de detective aplicada a la prensa? Cabe, entonces, la pregunta: ¿qué investiga la prensa? La respuesta es obvia: nada, toda vez que la narración del acontecimiento es simultánea: los narradores informan lo que, como cualquier otro curioso que se halle en el lugar del crimen, están viendo, y, muy importante; lo que declaran los portavoces autorizados. En esta narratividad mediática, el narrador arriesga su vida (o su puesto de trabajo) sólo si se excede en sus conjeturas.

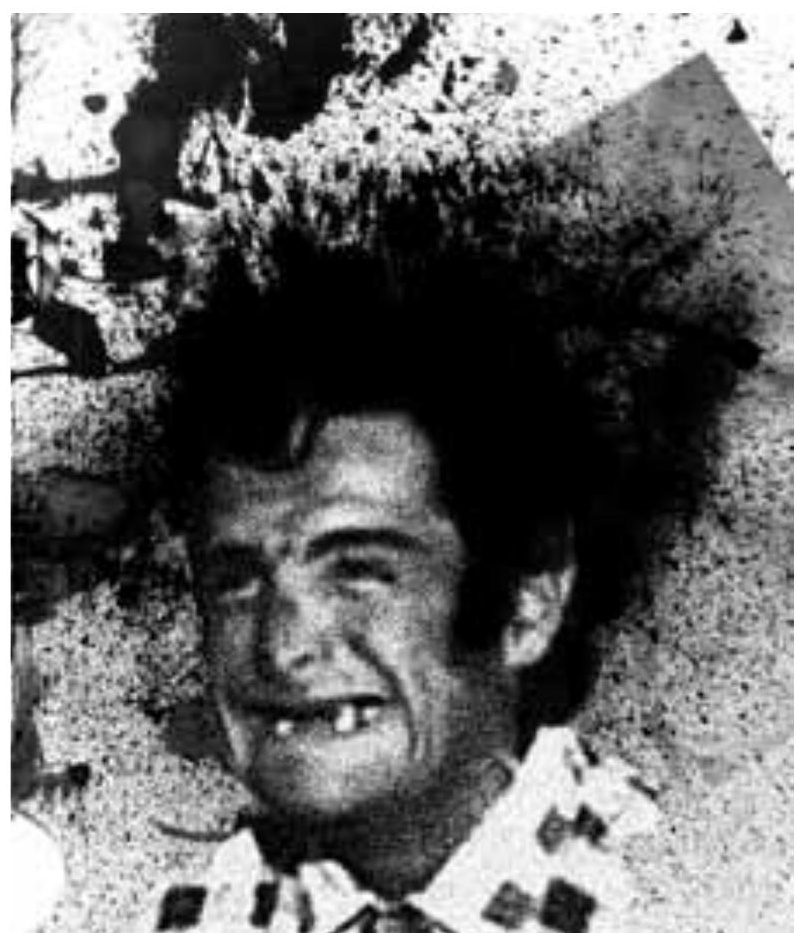

\section{La puesta en escena del simulacro: la búsqueda del culpable}

El evento mediático tenía rasgos excepcionales. $\mathrm{Mu}-$ cho antes que los familiares, al lugar del crimen llegó el Director Nacional de la Policía, el General Rosso José Serrano (condecorado por la DEA como el mejor policía del mundo) y con el general llegan también los agentes del CTI, de la DIJIN, de la SIJIN y del DAS, prácticamente casi todos los servicios secretos de inteligencia colombianos. Cercan la zona. Muy pronto encuentran testigos que, a pesar de los cascos de motociclistas que enmascaraban a los sicarios, están dispuestos a realizar la elaboración de un retrato hablado.

Ese mismo día, a las once de la mañana, dando muestras de una eficiencia inusitada o por lo menos no reservada para el común de los casos, la técnica morfóloga del DAS elabora un retrato hablado que será entregado a los medios de comunicación del el presunto asesino del periodista Jaime Garzón Forero. La fuente de dicha información será confidencial. Años después sabremos que la supuesta testigo se llama "María Amparo Arroyave Montoya, de cuya existencia duda la parte civil” (Alirio Uribe Muñoz, 2003). He aquí parte del texto de la declaración que sirvió para hacer el retrato hablado del criminal:

[...] Era un hombre joven como de veinte a veinticinco años como mucho, de tez como trigueño oscurito, labios normales y nariz perfecta, ojos pequeños, no les vi de qué color y con vista en el retrato hablado que aparece en el expediente elaborado por el DAS se parece bastante, coincide mucho con la persona que describo, como llevaba el pasamontañas como un turbante no le vi las orejas, no tenía ni bigote ni barba (Ibíd.). 
Con base en estas declaraciones de la excepcional testigo, días después serán capturados como presuntos homicidas, alias “El Bochas” y alias “Toño”. El retrato hablado, publicado en prensa y televisión, será la mayor prueba de la eficiencia de los organismos técnicos judiciales y de la policía del Estado.

La mecánica de la puesta en escena ha sido impecable. La prensa, que exige imperiosamente que en este caso no haya impunidad, no podrá negar el espectacular operativo policial. En efecto, hay testigos, hay un retrato hablado, hay anillos de seguridad para cercar la zona, con el fin de aprehender a los asesinos, y hay un cadáver caído sobre el timón de una camioneta Cherokee, el de un tal Jaime Garzón. El espectacular despliegue policial es escenificado para dos públicos. En primer lugar, para la prensa, primer doliente y observador narratorial; en segundo lugar, para el Gran Público telespectador, destinatario indirecto de la puesta en escena teatral (Kerbrat-Oreccionni, 1984 ). La prensa siente por y en el lugar del Gran Público que está pendiente de las informaciones proporcionadas, en directo, desde el lugar de los acontecimientos. Pero este público espectador, ¿de qué está ávido? La curiosidad por la identidad de los asesinos ha sido medianamente satisfecha con el retrato hablado de los presuntos sicarios, pero quedan pendientes los resultados de la persecución: ¿los van a atrapar? ¿Se van a escapar? ¿Será verdad?

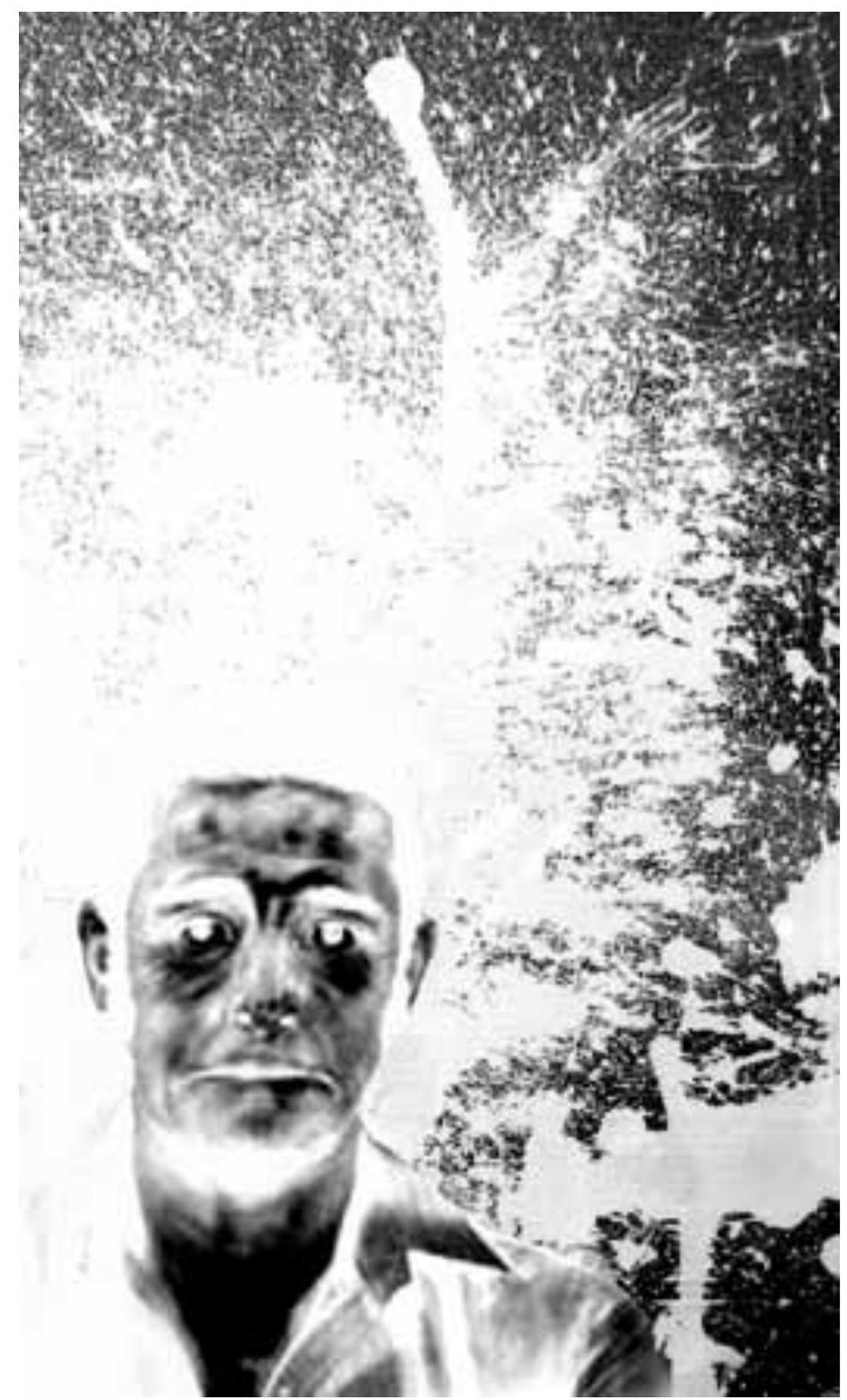

Evidentemente, en el presente de la narración simultánea, en caliente, desde el lugar de los hechos, el Gran público telespectador no va a conocer el cumplimiento de la promesa del género negro: la captura de los actores materiales del crimen y, sobre todo, el conocimiento de la identidad de los actores intelectuales y sus los móviles. En lugar de esto, la labor conjunta de los servicios de inteligencia y de la prensa estimulan la dramatización: la presencia en el lugar de los hechos de grandes personalidades de la Policía y de la Fiscalía representan la buena voluntad de los encargados de las instituciones destinadas a castigar a los infractores de la ley; los familiares y los curiosos representan el pathos en los límites más extremos de la sorpresa, el horror; la prensa se muestra a sí misma, como deudo, reclamando justicia. El reparto de personajes en escena constituye un acto inicial, ante le cual el tercero indirecto de la comunicación, el telespectador, está conminado a permanecer en antena, pendiente del hilo de la narración de los hechos. Este telespectador está modalizado prioritariamente por tres formas de la pasión: el recuerdo, que corresponde al tiempo del fantasma donde el comediante sigue vivo; el duelo, que lo instala en el presente de la falta, y, finalmente, la espera, que lo proyecta al futuro: la espera remite a la esperanza de la venganza, en este caso, un tipo de retaliación amansada, delegada a las instituciones policiales y judiciales. 
Mientras tanto, a falta de la resolución del enigma del género negro, en compensación, la prensa estimula el pathos. Un ejército de periodistas de diferentes medios compite por conformar el archivo del macro-relato mediático. Mientras unos registran los hechos que ocurren en directo, en el lugar de los acontecimientos, otros buscan los archivos para construir la historia pública del personaje mediático, y otros rastrean fuentes de diversa procedencia: colegas de la radio y la televisión, familiares, amigos, vecinos, personajes que otrora fueran entrevistados por Garzón cuando era Heriberto de la Calle o parodiados por él cuando realizaba Zoociedad o Quac. Cualquier información sirve para darle volumen al pathos, que se nutre de recuerdos en un duelo cada vez más comunitario, con el fin de satisfacer y excitar las expectativas del gran público telespectador que sigue y participa en el desarrollo del drama.

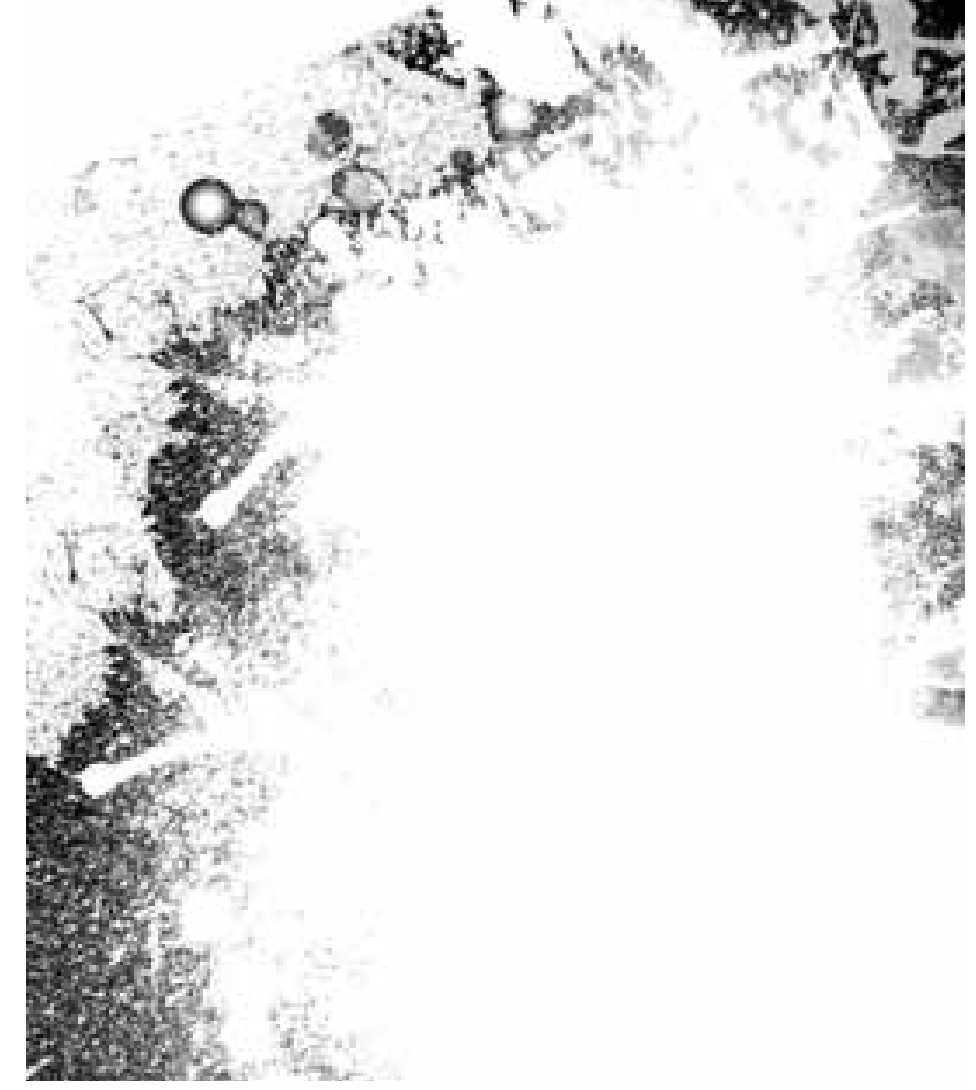

\section{El rechazo del simulacro policial y el señalamiento del autor intelectual}

La exhibición de las grandes personalidades de la policía y de la fiscalía en el lugar del crimen, la mecánica de los dispositivos de seguridad, así como los operativos en plena acción, suelen ser suficientes para satisfacer las necesidades narrativas de la prensa. Pero, esta vez, los periodistas muy conocedores de la puesta en escena de los simulacros policiales que, en esencia no garantizan nada, pasan por alto la presunta importancia del retrato hablado, del cerco de seguridad de la zona y de los presuntos operativos de persecución de los asesinos. Estos son señuelos que la prensa sabe sazonar muy bien para el Gran Publico. Pero, esta vez, por tratarse de un colega, de una celebridad amada, los periodistas desdeñan esos simulacros. Más importantes son las especulaciones sobre la identidad de los autores intelectuales, los móviles y los objetivos que preceden al magnicidio. La hermenéutica de este tipo de narratividad en Colombia, puede ser letal.

Es así que, haciendo caso omiso del simulacro policial, sin suspicacias, sin necesidad de investigación previa, sin respeto al debido proceso, un periodista de RadioNet dijo, sin ambages, que el atentado contra Jaime Garzón tenía nombre propio: Carlos Castaño:

Después de las primeras palabras introductorias de Aída Luz, dando la triste noticia, yo, que ya sabía que quien lo había mandado matar era Castaño, con más sentimiento que responsabilidad dije al aire: "Señor Carlos Castaño: usted es un hijo de puta". Días después me encontré en la librería Lerner con mi amigo el poeta Mario Rivero, quien me saludó diciéndome: “Maestrico: ¿Usted todavía está vivo?” Ante mi cara de extrañeza él me tuvo que recordar la razón de su sorpresa, y yo le dije: 'Poeta, tuve la suerte de que Castaño no oye Radionet' (Guillermo Ángulo Peláez, 1999) 
La lógica narrativa del thriller mediático exige esta función, la presentación de las hipótesis sobre la identidad del culpable. Así como el público espectador se hace conjeturas sobre los posibles asesinos, los periodistas también. El duelo es el estado pasional que autoriza a los periodistas la transgresión de la aparente neutralidad y el supuesto distanciamiento objetivo al que están obligados. En el terreno narrativo, los periodistas se convierten en héroes del decir la verdad, por ende, del tener el coraje de señalar a un anti-héroe temido por todos y, más aún, de poner en la caja de resonancia mediática la palabra pasional por excelencia de los colombianos, jueputa, al caso en el insulto directo, "hijo de puta". El país recordará como acontecimiento, en el sentido de ruptura, de salida del libreto, de emergencia de la subjetividad, el famosísimo: "Y hasta aquí los deportes. ¡País de mierda!" enunciado por el periodista César Augusto Londoño (CM\&, 13/08/1999).

\section{La desmentida categórica y la orden sutil}

Interpelado por la prensa, señalado como autor intelectual del asesinato, Carlos Castaño (el único jefe visible en ese entonces de las Autodefensas Unidas de Colombia, AUC, un ejército paramilitar que presumía de contar con más de 27.000 mercenarios en el país), aparece en escena unas horas después de la acusación de los periodistas de RadioNet: "Pasadas las ocho de la mañana, el propio Castaño desmintió en un comunicado a Caracol cualquier relación con el crimen, y las investigaciones quedaron así sumidas en el camino de la confusión” (Cambio, ed.322, 08/16-23/1999:20).

Otra versión, más completa de la desmentida aparece en la misma revista Cambio ocho días después, mediante un relato presentado en dos secuencias:

"Orden dada. Según un relato que Garzón les hizo a varios de sus colegas, durante la charla él le pidió a Castaño que no lo matara, pero el jefe de las autodefensas le contestó que la orden ya estaba dada. El periodista le propuso que lo recibiera durante el fin de semana, para explicarle en que consistían sus gestiones en materia de secuestros. Según el relato de Garzón, Castaño puso en duda que Garzón tuviera el valor de darle la cara. Garzón insistió y Castaño finalmente aceptó recibirlo. Definieron algunos detalles de procedimiento antes que Garzón le preguntara qué iba a pasar con la orden de matarlo. Según lo dicho por el humorista, Castaño se limitó a decirle que tratara de sobrevivir hasta que pudieran verse”

"Desmentido. Sin embargo el jueves pasado Castaño envió a la Defensoría del Pueblo un comunicado en el que asegura que nunca amenazó a Garzón, que jamás acordó con él una reunión y que mucho menos lo mandó a matar. Periodistas de RadioNet dijeron haber recibido llamadas de Castaño en las que negó haber ordenado el crimen, pero en las que reconoció haber cometido el error de amenazar a Garzón” (Cambio, ed.323, 23-30/08/1999: 20). 
La cita anterior condensa la intriga del argumento de una novela negra, con una enorme carga de suspenso: el protagonista es un humorista y periodista (Jaime Garzón) tratando de sobrevivir hasta encontrar al hombre que dio la orden de asesinarlo (Carlos Castaño). Pero la orden está dada y es irreversible. Sólo escapando a la infalible e incontrolable máquina de muerte, Garzón podrá obtener una segunda oportunidad: una cita concedida por el magnánimo jefe del ejército paramilitar, dispuesto a escuchar las explicaciones del condenado, si éste logra escapar a la muerte.

Hasta aquí podemos observar la principal características narrativas del thriller construido en el seno del relato telenovelesco: prioritariamente, es preciso destacar que el relato periodístico cumple una función de interfaz de voces narrativas que permite, por una parte, a la instancia narratorial (periodistas) decir la identidad del autor intelectual del crimen (Carlos Castaño) ante el público telespectador.Y, por otra parte, permite al presunto asesino responder a tal acusación (enviar un comunicado) con el fin de defenderse desmintiendo su participación en el asesinato. Y, más interesante aún, obligando a la instancia narratorial a corregir el relato, a redefinir los modos de la narración y, por lo tanto, la historia misma. A partir de la aparición de Carlos Castaño cesa la producción de efectos de novela negra en el relato periodístico, en lo que atañe al interés por la exploración y puesta en evidencia de "la banalidad del mal". En adelante, el relato reviste las características de thriller legitimante del statu quo.

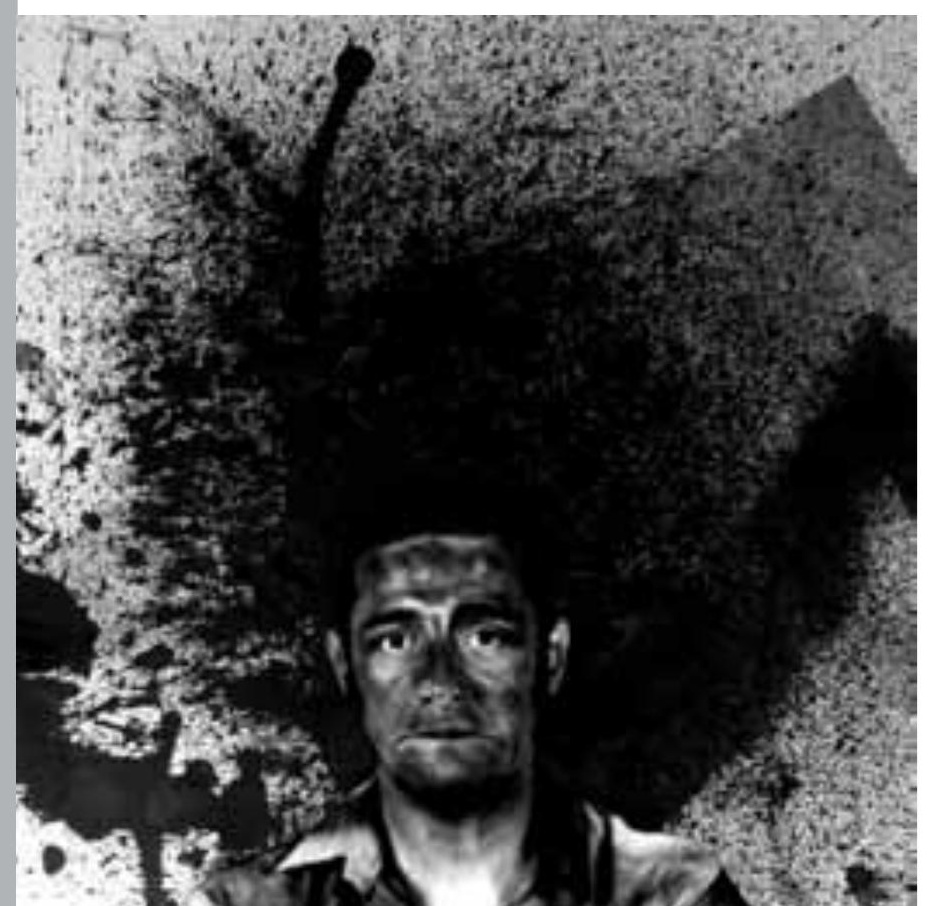

\section{La cortina de humo}

El breve momento de heroicidad de los periodistas no dura mucho. Después del comunicado de Carlos Castaño Gil, el periodismo regresa al rol del informador aparentemente "neutral", mediante los simulacros discursivos del distanciamiento objetivo. Casi obedeciendo al acto indirecto generado por el comunicado de Carlos Castaño (fenómeno de metalepsis ${ }^{6}$ narrativa en el que un sospechoso da órdenes al narrador de corregir su relato y, por lo tanto, la historia), la prensa pasa, de la denuncia explícita y puntual del asesino, a la enumeración de posibles autores intelectuales y presuntos móviles. El ideal de la responsabilidad enunciativa del periodista ordena que éste, en tanto informador narratorial, se borre ante los puntos de vista de los actores sociales y que ceda la palabra a puntos de vista antagónicos (Ravatel y Chauvin-Vileno, 2006:20). De manera que, según diferentes géneros periodísticos, la instancia narratorial hablará en nombre propio (artículos de opinión) o se borrará en el colectivo que hace un dossier especial que pone en escena las voces de diferentes enunciadores (fuentes autorizadas y personalidades del mundo institucional, principalmente). No obstante, como diceVion, "el punto de vista periodístico está ahí: jugando al escondite detrás de algunas opiniones, acampando abiertamente en otras, manifestándose en una posición menor o en contrapunto y, finalmente, re-apropiándose, más o menos violentamente, de una posición dominante" (Vion, 1998:196-199. Traducción nuestra). En las cita que veremos a continuación, a propósito de la construcción de la cortian de humo, observaremos los dos modos de manifestación de la instancia narratorial, la que expresa la opinión a nombre propio y la que se borra en el colectivo que hace el dossier especial. 
El thriller con efectos de novela negra deja la sensación de la impunidad, lo que en términos de la sintaxis del relato consiste en el final abierto: el criminal sigue libre y es inalcanzable. El ciudadano cualquiera está inerme; los periodistas que han reclamado justicia por la muerte de uno de los suyos quedan advertidos, cualquiera puede ser el siguiente: "La víctima es un personaje esencial de la novela negra, posicionamiento en el que todo el mundo puede arriesgar su vida a cualquier momento" (Reuter, 2005: 61). Otros efectos de género toman el relevo en el macro-relato mediático, la elegía y la farsa.

\section{El mercado de las pasiones: el carnaval y la elegía}

A falta de una resolución del enigma detectivesco, el macro-relato mediático, destinado a satisfacer las necesidades narrativas de los telespectadores, ese actante doble: clientes a entretener y ciudadanos a informar (Charaudeau, 2005), se inclina por las informaciones concernientes a la reconstrucción de la obra del artista. Los personajes ficcionales creados por Jaime Garzón serán tratados como seres vivos que perecen con la muerte del comediante. En este sentido, la metonimia autor/ obra es la que posibilita la fusión de mundos posibles. De manera alternada, las imágenes referentes a la ficción son complementadas con las imágenes de archivo de las entrevistas hechas a Jaime Garzón. Dos fondos musicales acompañan el sol negro del duelo, uno elegiaco y otro de fiesta. El primero con la versión del poema de Miguel Hernández, Elegía ${ }^{11}$, cantado por Joan Manuel Serrat, y el segundo con la canción de César Mora, Canela, interpretada por el mismo Jaime Garzón. El oxímoron que hemos tomado prestado de Georges Bataille, el sol negro, sirve para señalar la coexistencia de la tristeza y la alegría, de la ternura y la rabia y la impotencia y la orfandad.
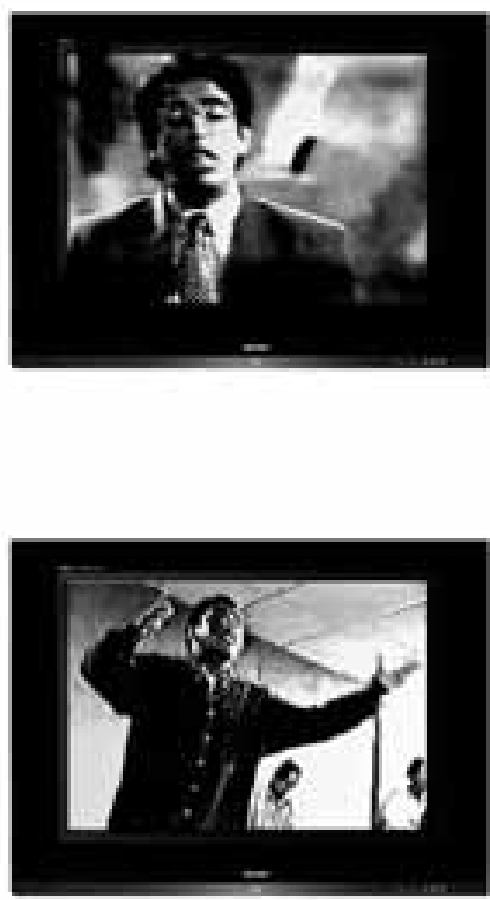

\section{La función aleccionadora del thriller}

Contrario a la novela negra en la que la crítica social es fundamental, es decir, en la que el orden no suele triunfar, el thriller periodístico se postula como un restablecimiento del orden, como triunfo de las instituciones. Dicho en otras palabras, el thriller periodístico es una prótesis imaginaria: colma la falta de la justicia. Contrario al Proceso 8.000 donde se proclamó el triunfo del periodismo independiente, de la policía y de la justicia, en el macro-relato de la muerte de Garzón, el thriller apunta a otra forma de éxito: el triunfo de la instancia ciudadana reunida masivamente para decir "No a los violentos".

En el contexto de frustración, impotencia, orfandad, los medios de comunicación promueven una movilización popular para acompañar el féretro de Jaime Garzón. La respuesta fue masiva y un indicio basta para dar cuenta de ello: hubo tres muertos más a causa del derrumbe de un puente peatonal por sobrepeso de dolientes. La prensa habla de una movilización de cuatrocientas mil personas en las calles de Bogotá. Lo interesante es que la asistencia no fue espontánea y que ningún medio de comunicación en particular se arroga la autoría de la iniciativa (lo que recuerda algunas movilizaciones supuestamente espontáneas, es decir, sin la bendición del gobierno, hechas a través de redes sociales como Facebook, contra la guerrilla de las FARC, el 4 de febrero de 2008). He aquí el texto aparecido en primera plana de uno de los llamados a la convocatoria: 

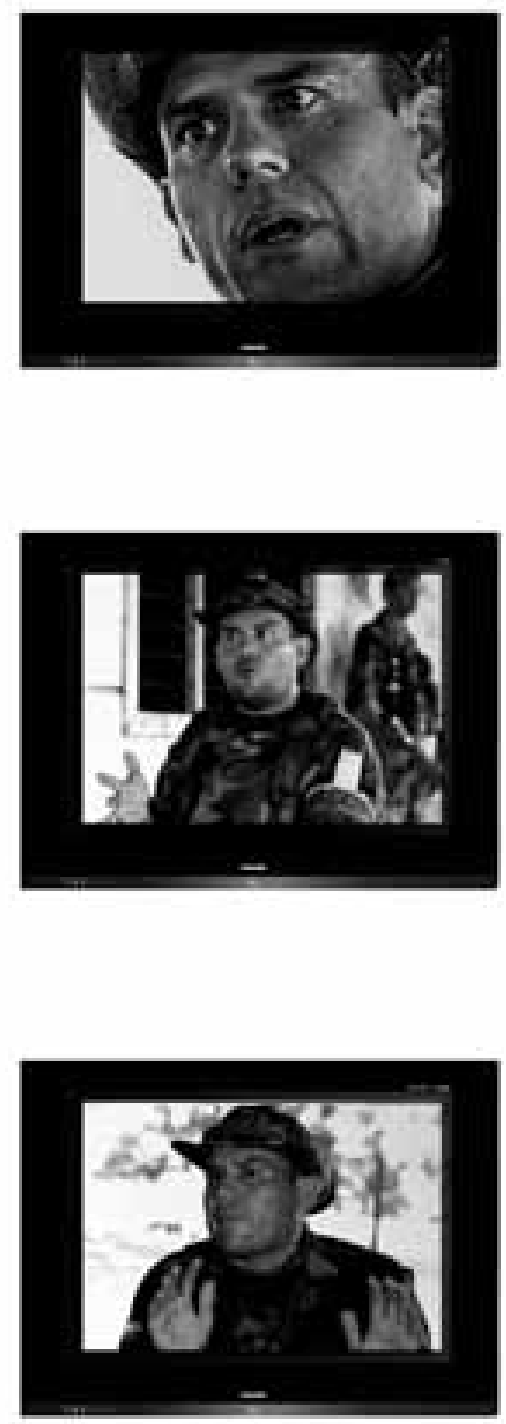

\section{Hoy, el país dirá No Más}

Ayer fue Manizales. Hoy será Bogotá la que diga: NO MÁS.

Han matado a otro hombre joven, a otro colombiano trabajador, honesto, conciliador, tolerante. Y los colombianos agobiados por la violencia piensan abandonar la indiferencia para enviar un mensaje de rechazo a los amigos de las armas.

La convocatoria empezó a circular ayer de boca en boca y por los medios. Y al caer la tarde ya en el barrio La Perseverancia y en la Plaza de Bolívar de Bogotá se empezaron a concentrar los ciudadanos con pañuelos blancos y velas encendidas.

Hoy a las dos de la tarde el país rendirá homenaje a Jaime Garzón y a todos los que como él han dado su vida por una patria mejor. La cita es en la Plaza Bolívar y en todas las plazas del resto de ciudades (El Tiempo, 14/08/1999) ${ }^{12}$

Lo interesante de este texto es que no se nombra la identidad de ningún actor social de la violencia como responsable del asesinato. La autoría se diluye en un calificativo genérico, "los violentos". Por otra parte, la masiva movilización popular recuerda que un dolor semejante, años atrás, con la muerte del líder político liberal Jorge Eliécer Gaitán, desembocó en actos de venganza que tuvieron como blanco metonímico las instalaciones del periódico El Siglo e iglesias que, para la masa, identificaban a los enemigos del caudillo. Contrario a esa turba furiosa del 9 de abril de 1948, con la muerte de Jaime Garzón hallamos una multitud controlada, que avanzaba en procesión, cívica en su protesta, portando pañuelos blancos y pancartas con mensajes dictados por los medios: "Basta", "No a los violentos".

Gran número de personalidades representativas de los campos político, militar, judicial, periodístico y artístico del país expresan su dolor y testimonian su afecto por Jaime Garzón a través de los medios de comunicación. La iglesia -obviamente- y hasta el ex embajador de los Estados Unidos de Norte América, Mylles Frechette, tuvieron palabras para hablar de Garzón. En esta democratización del duelo, el pueblo participó masivamente con sus pancartas, poemas, grafittis, rosas depositadas en el lugar del crimen. La democratización del duelo estuvo a la par con la generalización de la culpa como un modo de exorcizar colectivamente la fatalidad. Al respecto se pueden mencionar las declaraciones de Mylles Frechette:
Garzón era un humanista y es una gran pérdida para el país, que me entristece. El mensaje de Garzón era de esperanza y de optimismo. Haber silenciado esa voz es un crimen terrible. A los colombianos les hará falta. Colombia, para solucionar sus problemas, tiene que hablarlos abiertamente y no pegarle balazos a la gente que habla. Se acabó el comodísimo y cada quien tiene que poner de su parte para solucionar los problemas (El Tiempo,14/08/1999:7A)

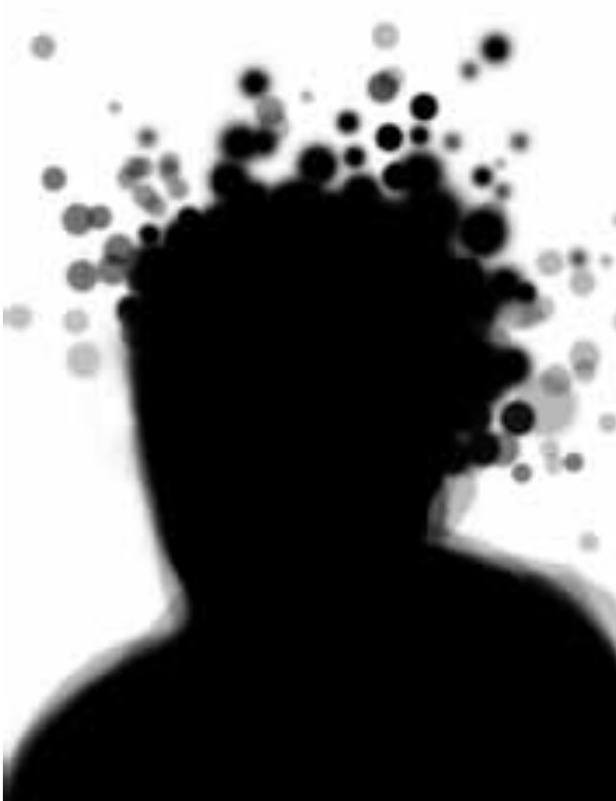


La acusación retórica es tan clara como la moraleja: a falta de un culpable, todos los colombianos somos responsables del crimen.Y eso tiene una explicación causal: nuestro modo de solucionar los problemas a balazos. Para el vocero de la mayor y más "ejemplar" democracia del mundo, los culpables de la muerte de Garzón somos 44 millones de colombianos.

Para concluir, podemos decir que la estructura de base de la narratividad de los macro-relatos mediáticos en Colombia, aquella que describe Germán Rey a propósito de las acciones realizadas en el marco de los combates guerrilla-ejército: "Enfrentamiento - Muertes- Declaraciones - homenajes o exposición aleccionadora - olvido" (1998:230), se cumple parcialmente. Lo que cambia, lo que introduce el thriller periodístico de la muerte de Jaime Garzón, y lo que hace de este macrorelato algo singular en la historia del periodismo colombiano, está en los siguientes estadios, que expuestos en forma sumaria son:

- Muerte

- Narración detallada de la puesta en escena del simulacro policial

- Rechazo de tal simulacro por parte de los periodistas

- Acusación de los periodistas a Carlos Castaño como autor intelectual del crimen

- Rechazo de la acusación por parte de Carlos Castaño (y modificación del macro-relato mediático)

- Homenajes

- Exposición aleccionadora

Lo nuevo es el rechazo del simulacro, la acusación del "verdadero asesino" y la posterior desmentida de tal acusación por parte de Carlos Castaño. Es en estas partes del trayecto narrativo donde se da el efecto de novela negra en el macro-relato mediático. Después de la intervención de Castaño, el macro-relato gira hacia el thriller aleccionante, moralizante, hacia el cierre retórico del si todos culpables, ningún culpable, y finalmente, hacia la función que clausura el proceso, el olvido. Pero también es preciso decir que este canónico olvido no sucede. Digo "canónico" para hacer referencia tanto al esquema de Germán Rey, como al ritmo metonímico de las noticias en las que la última primicia borra, elimina, hace olvidar a la anterior. En efecto, lo relacionado con el olvido, en este singularísimo caso no sucede, pues cada año la mayoritaria prensa oficial -hasta ahora- ha vuelto al homenaje (sólo al homenaje) que es presentado de manera similar a como vuelve un síntoma: algo no asimilado, no aceptado, no tramitado.
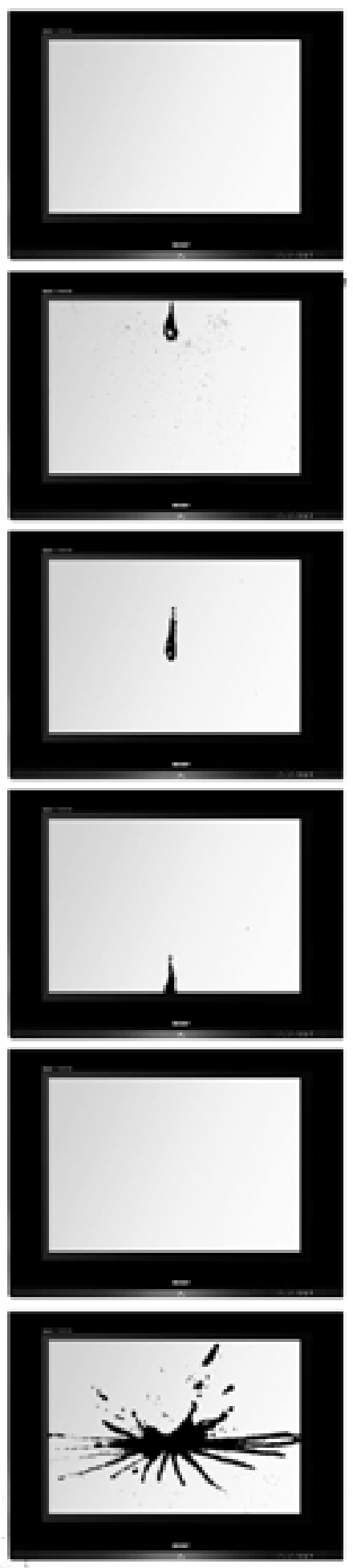


\section{Anexo : Esbozo de fenómenos discontinuos}

Desde la perspectiva de los efectos de género aplicados al periodismo, el thriller mediático en el caso de la noticia del asesinato de Jaime Garzón es un entremés, una pieza en medio de representaciones serias: el la planeación y ejecución del asesinato, por una parte, y, por otra, la investigación politológica y la investigación judicial. Lo anterior nos sirve de introducción es para decir que el crimen de Jaime Garzón es punto de referencia de algunos fenómenos políticos de gran relevancia. Cito a manera de enumeración algunos de esos fenómenos posteriores a su asesinato.

- Durante el funeral de Jaime Garzón, con la consigna de "No a los violentos" orquestada por los diferentes medios de comunicación, logra gran popularidad Francisco Santos, dirigente de la fundación País Libre. La multitudinaria movilización contó como plus del capital simbólico de su movimiento, aquel que lo llevaría a la Vicepresidencia de la República durante los dos periodos del mandato de Álvaro Uribe Vélez.

- Tres meses después del duelo masivo y de la expresión dócil del descontento popular a causa de la muerte del humorista, La campaña "No a los violentos", tendrá otro giro a través de la campaña institucional llamada "Acuerdo por la discreción”, en la que una treintena de directores de medios pactan presentar noticias que sólo favorezcan los intereses del Estado y apoyen a la fuerza pública (ver análisis en Cortés-Tique, 2006).

- Durante varios años, sin las turbulencias del escándalo mediático, los defensores de los derechos humanos se apersonan como veedores de las investigaciones judiciales por el caso del asesinato del humorista. Dos fallos se conocen a propósito del caso del asesinato de Jaime Hernando Garzón Forero, el primero del 4 de octubre de 2002 y otro del 10 de marzo de 2004. La prensa registra sin despliegue narrativo los resultados del último fallo: la condena a Carlos Castaño Gil como reo ausente a 38 años de cárcel y una multa por 790 millones de pesos. Un informe de los vaivenes del juicio es publicado a través de internet y en él se detallan todos los aspectos del singular falso positivo - en el sentido de simulacromontado por el DAS y avalado por la Fiscalía.

- El periodista Hollman Morris pone en evidencia el fenómeno del falso positivo en el sentido de montaje de falsos testigos, falsos asesinos, falsas investigaciones. Morris hace dos especiales de su programa Contravía sobre el humorista. El primero titulado “El asesinato de Jaime Garzón” (2008) y el segundo, “Jaime Garzón 10 años de impunidad" (2010). Este segundo especial refleja las crisis generadas por las confesiones de los paramilitares en los últimos años ${ }^{13}$, respecto a temas aún no esclarecidos: las relaciones de paramilitares con la cúpula del ejército y de los paramilitares con el DAS (El Tiempo, 23/04/2009) y, particularmente, el señalamiento del subdirector del DAS, José Miguel Narváez como instigador del homicidio del humorista. 
- Una lectura transversal del Informe de la Parte Civil ( Colectivo de abogados José Alvear) en el caso de Jaime Garzón, con un artículo de prensa titulado "Un país de chuzados" (El Espectador, 28/10/2004) y con un aparte del libro "La Censura de fuego" (2004), ofrece algunas pistas para reconstruir las claves de, esta vez sí, una novela negra contemporánea. Todo parte del secuestro del industrial judío de origen libanés, Benjamín Khoudari, quien muriera durante el secuestro ${ }^{14}$. Al parecer, Jaime Garzón se enteró de que tal industrial fue secuestrado por un grupo perteneciente a los servicios de inteligencia del Ejército, que tenía en cabeza de mando al Coronel Jorge Plazas Acevedo. El industrial Benjamín Khoudari muere y, a pesar de eso, es cobrado el rescate. Jaime Garzón, entonces mediador para la liberación de secuestrados, se entera del caso, como también los servicios de inteligencia se enteran que Jaime Garzón conoce el sórdido secreto. La posesión de ese saber lo condena a muerte. Acto seguido, viene el asesinato. Todo ha sido cuidadosamente preparado: la falsa testigo que ofrece el retrato hablado, el informante profesional del DAS, alias "El profesor", que funge como testigo contra "Toño" y "El Bochas", los supuestos asesinos. Los detectives de esta novela negra son miembros del colectivo de abogados José Alvear. Los abogados defensores de derechos humanos desmontan pieza por pieza la puesta en escena del simulacro. Mientras tanto, otras pruebas van llegando... y desapareciendo. Hay participantes del crimen que quieren confesar. Todos son eliminados. Sin contar a los miembros de la banda de la Terraza, ocho nombres propios están en la lista; todos ellos virtuales declarantes cuyos testimonios habrían podido ayudar a esclarecer la intrincada trama, los detalles del operativo de asesinato, los detalles de la construcción del montaje y, finalmente, arrojar luces sobre la identidad y los móviles de los autores intelectuales. Pero todo eso es parte de otra ponencia. Ya he abusado demasiado de su Tiempo esta Semana.

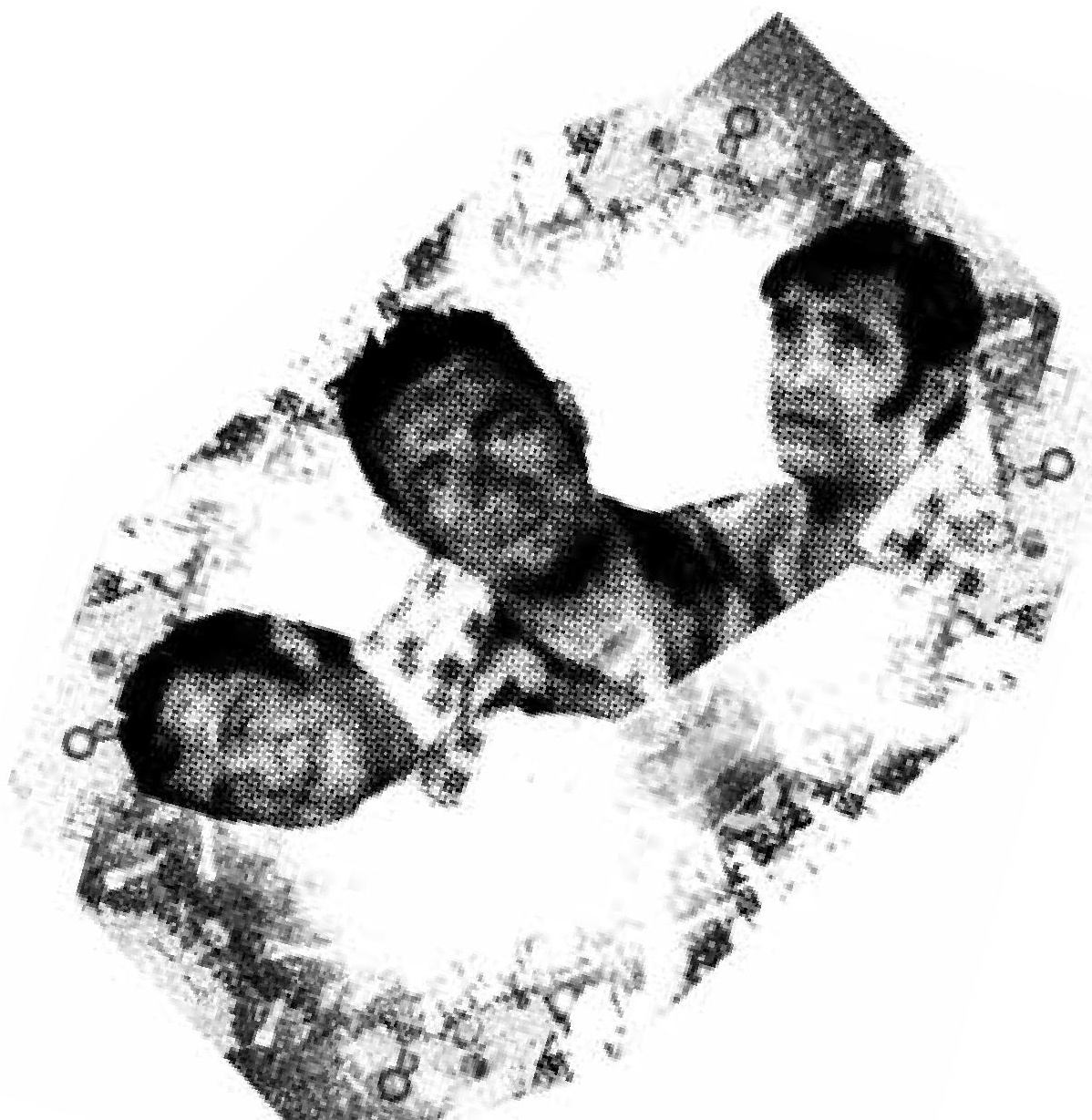


${ }^{1}$ Hemos construido la noción de macro-relato mediático con base en el análisis realizado por Lucrecia Escudero en su texto Malvinas, el Gran Relato (1996). En esa misma línea de sentido, la narratología post-clásica habla de Feuilleton médiatique. Expresión que, al pasar al castellano latinoamericano, remite a las tramas -a los culebrones- propios del género telenovela. Así pues, desde una terminología propia al mundo de las telecomunicaciones, bien podemos hablar de lo telenovelesco para aludir, tanto a los géneros de la ficción propios de la televisión, como para las dramatizaciones generadas en el seno del periodismo.

2 Para más detalles, consultar el libro El presidente que se iba a caer (1996), en el que se muestra en detalle la labor conjunta de investigación por parte de diferentes medios de comunicación y, de manera paralela, su posicionamiento en la conspiración política.

${ }^{3}$ Permítanme una digresión para presentar desde otro punto de vista la anterior tesis: si Jaime Garzón estuviera vivo, la noticia de un caso como el suyo habría sido contada por su personaje Frankenstein Fonseca, el encargado de la parodia burlesca de las noticias judiciales. Tal personaje evoca, por un lado, la ciencia ficción - al tomar el nombre del personaje creado por creado por Mary Shelley- y, por otro, la novela negra, al tomar el apellido del gran escritor de este género, Rubem Fonseca. De esta manera, el personaje Frankenstein Fonseca connota “cuerpo del delito” ensamblado por yuxtaposición de partes y de géneros, como el macro-relato mediático que aquí analizaremos.

${ }^{4}$ La expresión es está inspirada en el título de una obra de Nathalie Sarraute, "L’Ère du soupçon”/La era de la sospecha (1956).

${ }^{5}$ En el plano axiológico, el thriller no se confunde de ninguna manera con la novela negra contemporánea. Al respecto citamos dos autores, Jean Pons y Caroline Lepage. Par el primero, "La novela negra es una escritura comprometida y ofensiva, porque al exhibir los mecanismos que explican el porqué de las cosas y sus actos, denuncia los procedimientos de la mentira, de la alienación y de la violencia que encuadran el espacio social" (Pons, 1997:9. Traducción nuestra). En contrapartida, tal como lo define Caroline Lepage, el thriller lleva consigo una función socializante y tranquilizante, que no busca minar el sistema ni denunciarlo, sino legitimarlo: "El género que triunfa hoy en día en los Estados Unidos es lo que llamamos thriller, novela 'policial' por excelencia. Con la victoria del consenso floreciente, o más exactamente, re-floreciente de las figuras heroicas sin fisuras, al caso, de los policías o de los representantes de las fuerzas del orden en general, que por precarios que aparezcan en cuanto a los medios de que disponen para llevar a cabo su misión y por falsamente complejos que aparezcan en el plano psicológico, no por ello validan menos el sistema, el establecimiento, ya que sus hazañas, inscribiéndose, casi siempre, en un trabajo presentado como colectivo (el rol confiado por ejemplo a los expertos y a la ciencia en general es bastante significativo), no están vacíos de sentido, sino que apuntan prioritariamente al restablecimiento del orden social" (Lepage, 2006: 214. Traducción nuestra)

${ }^{6}$ Para el concepto de metalepsis narrativa, ver Gérard Genette, 2004.

7 "Varios medios han señalado que una de las hipótesis del asesinato recae en el Ejército. El editor general de El Tiempo, Francisco Santos, también lo señaló. ¿Por qué el ejército reacciona tan tarde? ¿Por qué los mandos del ejército reaccionan tan tarde? ¿Por qué Castaño desmiente su autoría y sí se le cree? Son preguntas que no pueden quedar en el aire ante la muerte de nuestro querido Jaime Garzón” (Rafael Pardo, “Garzón”, El Espectador, 18/08/1999). El contenido de esta columna será el objeto de una entrevista al General Jorge Enrique Mora Rangel, titulada "Yo no he absuelto a Castaño”, (Semana, ed. 903, pp 23-26.)

${ }^{8}$ La revista Cambio en su edición 325 del 23 de agosto de 1999 enumera treinta pistas.

9 "Según los expertos, el crimen de Garzón fue un crimen perfecto: 'Se llevó a cabo en una calle no residencial, de madrugada, lo realizaron dos sicarios en moto que no utilizaron la tradicional Mini-Uzi sino un revólver 38 porque sabían que esa arma no deja vainillas en el piso. Y lo hicieron desde una moto que tenía la placa tapada, o sea que no era robada', dijo a Semana una fuente de la Fiscalía” (Semana, ed.209:27)

${ }^{10}$ Esa racionalidad detectivesca, en la perspectiva de la novela negra, será asumida, en un segundo tiempo (ajeno a presente del crimen y del funeral), por los veedores de la investigación judicial, en el rol de representantes de la Parte Civil. En efecto los defensores de los derechos humanos, del Colectivo Alvear Restrepo, ponen en duda la estructura del simulacro: falsos testigos, falsos asesinos, falsas investigaciones y, por ende, ponen en duda la eficiencia del sistema judicial colombiano en pleno. La investigación, en este sentido, sí toma las formas de la novela negra, no hay legitimación alguna del status quo, la sospecha es generalizada, los "detectives" defensores de los derechos humanos amenazados de muerte, es el mal lo que impera, no la justicia.

11 "Elegía” es el título dado por Serrat al poema número 29 del libro El rayo que no cesa de Miguel Hernández.

12 Tiempo después se sabrá quién se atribuye como un éxito la protesta popular: "Francisco Santos Calderón creó en agosto de 1991 la fundación País Libre, primera Organización No Gubernamental (ONG) antisecuestro-en el mundo. Fue él quien, a través de esta fundación, movilizó a millones de colombianos en contra de los violentos y del secuestro, organizando los siguientes movimientos ciudadanos: en 1995-1996: 'Por el país que queremos NO AL SECUESTRO', marchas multitudinarias en las cinco principales ciudades colombianas, que logró movilizar más de cinco millones de colombianos. En 1997: 'Mandato Ciudadano por la Paz, la Vida y la Libertad', movimiento que, organizado junto con la UNICEF, la Red de Iniciativas por la Paz, (Redepaz), cientos de empresarios, 
la Iglesia y la academia nacional, movilizó a más de 10 millones de colombianos que introdujeron en las urnas el tarjetón verde de la Paz. En 1998 - 1999: 'NO MÁS’, movilizaciones por toda Colombia, promulgando No más Secuestros, No más desapariciones, No más actos violentos, entre otros.” Ver página web de la vice-Presidencia de la República. http://www.vicepresidencia.gov.co/Es/ Prensa/Noticias/2008/Paginas/080204a.aspx

${ }^{13}$ En los últimos cuatro años se han recibido las declaraciones de seis jefes paramilitares para acceder a beneficios de ley: Iván Roberto Duque, Jesús Ignacio Roldán, Francisco Enrique Villalba, Jorge Iván Laverde (alias “El Iguano”), Heber Veloza (alias “HH”) y Luis Eduardo Cifuentes. Laverde, paramilitar desmovilizado del Bloque Catatumbo de las Autodefensas Unidas de Colombia (AUC) , dijo en su declaración que el ex subdirector Nacional del Departamento Administrativo de Seguridad (DAS), José Miguel Narváez, instigó al jefe paramilitar Carlos Castaño Gil, para que asesinara al periodista Jaime Garzón. Por su parte, Veloza, aseguró que algunos militares también habían estado detrás del crimen.

${ }^{14}$ El secuestro tuvo lugar el 30 de octubre de 1998; un rescate de ciento veinte millones de pesos fue pagado; el cadáver de Benjamín Khoudari fue encontrado el 17 abril de 1999 en la ciudad de Pacho (Cundinamarca), en una finca del difunto Gonzalo Rodríguez Gacha.

\section{Bibliografía}

ARENDT Hannah y JASPERS Karl (1996), “Lettre à Jaspers, 7.9.1952”, [en] Correspondence. Paris: Payot.

Didier Maes). Paris: Payot \&Rivages. (1996 b)Considérations morales (trad. Marc Ducassou y

CHARAUDEAU Patrick (2005). Les médias et l'information: l'impossible transparence du Discours. Bruxelles: De Boeck \& Larcier, INA.

BOURDIEU Pierre (1996). Sur la télévision: suivi de l'entreprise du journalisme. Paris: Raisons d'agir. CORTÉS-TIQUE James (2006). "El discreto encanto de la censura en Colombia: apuntes sobre el humor periodístico en un contexto de corrupción”, [en] Humour et politique en Amérique latine, Yves Aguila (éd.), Bordeaux: Presses Universitaires de Bordeaux. (2008), Quac el noticero: humour, burlesque et meta-Journalisme en Colombie. Thèse du doctorat. Bordeaux: Université Michel de Montaigne.

(2009), “Noticia de un secuestro entre la mentira política y la ficción mercenaria” en Poligramas 30. Cali: Universidad del Valle, Escuela de Estudio Literarios, 2009.

ESCUDERO Lucrecia (1996). Malvinas: El Gran Relato. Fuentes y rumores de guerra. Barcelona: Gedisa, GENETTE Gérard (2004). Métalepse. De la figure à la fiction. París: Seuil.

KERBRAT-ORECCHIONI Catherine (1984), "Pour une approche pragmatique du dialogue théâtral”, [en] L'écriture théâtrale. Metz: CRESEF, Pratiques, $n^{\circ} 41$.

LOZANO Jairo y GONZÁLEZ Jorge (2004). La censura de fuego. Bogotá: Intermedio.

LEPAGE Caroline (2006), "L'humour dans la littérature Notre" [en] Humour et politique en Amérique Latine, Yves Aguila (éd.), Bordeaux, Presses Universitaires de Bordeaux.

PONS Jean (1997). «Le roman noir, littérature réelle », [en] Roman noir-Pas d'orchidées pour les TM. París: Les Temps Modernes, $\mathrm{n}^{\circ} 595$.

REVAZ Françoise (2009). Introduction a la narratologie. Action et narration. Bruxelles: De Boeck.

RAVATEL Alain y CHAUVIN-VILENO André (2006), "La question de la responsabilité dans l'écriture de presse". Franche-Compte: Semen, N ${ }^{\circ} 22$.

REUTER Yves (2005), Le roman policier. París: Armand Colin.

REY Germán (1999), Balsas y medusas. Visibilidad comunicativa y narrativas políticas. Bogotá: Cerec, Fescol, Fundación Social.

TODOROV Tzvetan (1971), “Typologie du roman policier” [en] Poétique de la prose. Paris: Seuil. URIBE MUÑOZ Alirio, «Referencia: Alegato para la sentencia. Radicado No. 402-7 por el homicidio del periodista Jaime Hernando Garzón Forero», 2003 [en línea], disponible en: http: / /www. derechos.org/nizkor/colombia/doc/alegato.html>, (consultado el 06/07/2007).

VION R (1998). "Du sujet en linguistique” [en] R.Vion (éd). Les sujets et leur discours. Énonciation et interaction, 189-202. Publications de l'Université de Provence.

VARGAS Mauricio, (1996). El Presidente que se iba a caer. Diario secreto de tres periodistas sobre el 8.000. Bogotá: Planeta. 


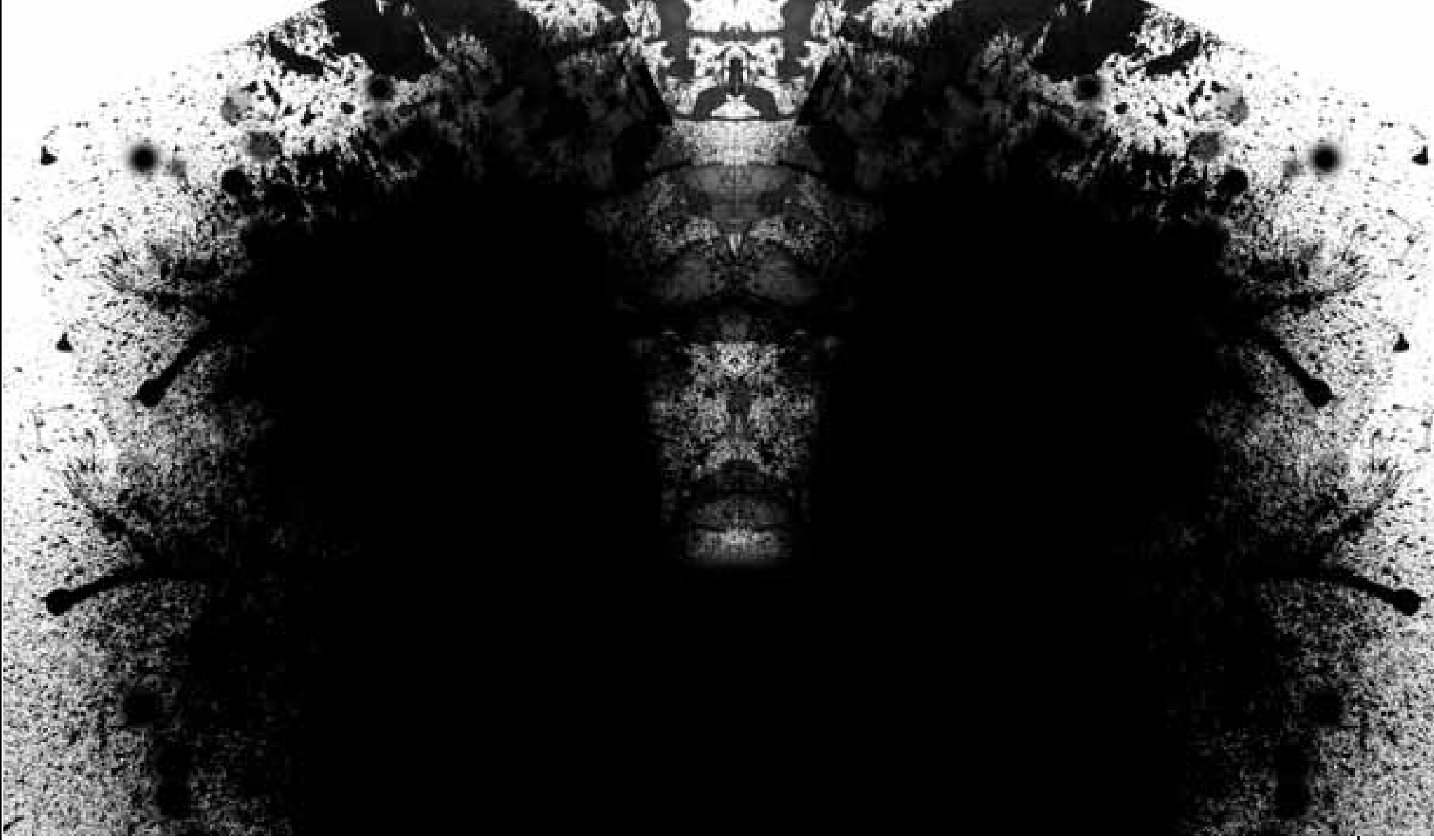

\section{Sitografía y mediateca}

Ángulo Peláez Guillermo , Jaime Garzón, la sonrisa sin dientes. Bogotá: secretaría de Cultura, Educación y Deporte, ciudadviva, noviembre de 1999. [en línea], disponible en :

<http: / /www.ciudadviva.gov.co/noviembre09/magazine/1/> (consultado el 30/08/2010)

"Los Amenazados", en sección secretos, Cambio, 23 agosto de 1999.

Cambio, ed.322, semana del 16-23, agosto de 1999.

Cambio, ed.323, semana del 23-30, agosto de 1999

Contravía, "El asesinato de Jaime Garzón”, Morris producciones, 2008.

Contravía, "Jaime Garzón 10 años de impunidad”, Morris producciones, 2010.

CM\&, sección deportes, 13 agosto de 1999.

El Espectador, 18 agosto de 1999.

GARZÓN Jaime, Conferencia para los estudiantes de comunicación social-Periodismo [videocasete]. Cali: Universidad Autónoma de Occidente, 1997.

“Un país de chuzados", El Espectador, sección judicial, 28 de octubre de 2004, [en línea], disponible en : < http:www.elespectador.com/judicial/nota9.htm> (consultado el 28/10/2004).

Semana, ed.902, semana del 16-23, agosto de 1999

Semana, ed.903, semana del 23-30, agosto de 1999

El Tiempo, 14 de agosto de 1999.

El Tiempo, 15 de agosto de 1999.

ElTiempo, 23 de abril de 2009.

Vicepresidencia de la República de Colombia. "Vicepresidencia se une a marcha "no más FARC". Bogotá: Febrero 4 de 2008 [documento en línea ] disponible en: <http: / / www.vicepresidencia.gov. co/Es/Prensa/Noticias/2008/Paginas/080204a.aspx> 


\section{EL HOMBRE APURADO Y SU IMAGEN EN LA GRAN METROPOLI ${ }^{1}$}

\section{THE RUSHING MAN AND HIS IMAGE IN THE BIG CITY}

Por

\section{Pedro José Duque López ${ }^{2}$}

Profesor del Programa de Diseño Gráfico

Universidad de Bogotá Jorge Tadeo Lozano

pedro.duque@utadeo.edu.co

\section{Resumen}

El cambio producido por la revolución industrial generó un desplazamiento del mundo rural al urbano, fenómeno que no sólo se manifestó en la producción de máquinas y la construcción de fabulosas factorías, sino en la percepción por parte de los citadinos de un nuevo espíritu de progreso y una sensación de velocidad, higiene y vida moderna. Esta percepción se transmitía por medio de imágenes impresas en las carátulas de revistas y primeras páginas de los periódicos expendidos en los puestos de venta, o masificadas mediante carteles publicitarios desplegados en las grandes ciudades. El presente artículo pretende ampliar el análisis de esas ideas y relacionarlas con el mundo gráfico que, a manera de espejo, convivió y reflejó la época motivo de la mirada de Clair y evidenciar una vez más la capacidad de la imagen impresa como fuente para el estudio y análisis de la historia.

\section{Palabras claves}

Automóvil, cartel, ciudad, imagen, individuo, industrial, moda, mujer, revista, velocidad.

\footnotetext{
1 El término hombre apurado se extrae de la lectura del texto y las ideas planteadas por Jean Clair (1988), "Red October, Black October, The 1920, age of the Metropolis" (trad. de Jorge Alberto Mejía) para los textos de la Maestría en Historia y Teoría del Arte y la Arquitectura de la Universidad Nacional de Colombia, Bogotá D.C.

${ }^{2}$ Maestro en Bellas Artes, M. Sc. Teoría e Historia del Arte y la Arquitectura
} 


\section{Introducción}

En los albores del siglo XIX se palpaba un cambio en las dimensiones geográficas de las ciudades europeas, su arquitectura y su espíritu. El desarrollo de nuevos materiales entre ellos el acero reforzado y el concreto, y mejores maquinarias, como la grúa, además de la implementación de una consecuente expansión de vías de comunicación terrestre, motivaron y facilitaron el desplazamiento de enormes masas de turistas, viajeros y emigrantes entre ciudades o regiones diferentes del centro europeo. Viajar entre las grandes capitales como París, Berlín o Roma era cada vez más fácil y rápido, las distancias y los tiempos se acortaron de manera notable.

Este fenómeno repercutió en la acelerada expansión y desbordado crecimiento de las ciudades. Sus habitantes comenzaron a percibir y sufrir sensaciones de aglutinamiento en los centros, congestión en las calles comerciales y distanciamiento entre los lugares de vivienda y el trabajo. La percepción de distancia y tiempo comenzó a variar de una manera silenciosa que no se sentía que afectara la vida y rutina diaria. Simultáneamente, el paisaje urbano sufrió un cambio radical pasando de horizontal a vertical, gracias a la construcción de edificios cada vez más altos con materiales más livianos y con la implementación del vidrio y la pared falsa móvil como parte de la nueva arquitectura. La reducción del tiempo de desplazamiento aunada a la aglomeración, no dejaban campo ni momento para el análisis ni concientización de tal fenómeno por parte de los ciudadanos.

Estos cambios inicialmente no fueron detectados o percibidos por ese habitante que igualmente experimentaba, a la par con la ciudad, modificaciones en su forma de vida, en su rutina, en su psicología, y en las imágenes que sus ojos apreciaban dentro de ese paisaje urbano que mutaba a su alrededor. ¿Cómo se dio cuenta este individuo que estaba cambiando? ¿Qué cambió? ¿Cuáles fueron esas señales visuales que le mostraban las transformaciones que se estaban produciendo? Se trata de considerar estas cuestiones.

Figura 1: La torre de Babel, 1563

Fuente: imágenes google.com. Pieter Bruegel

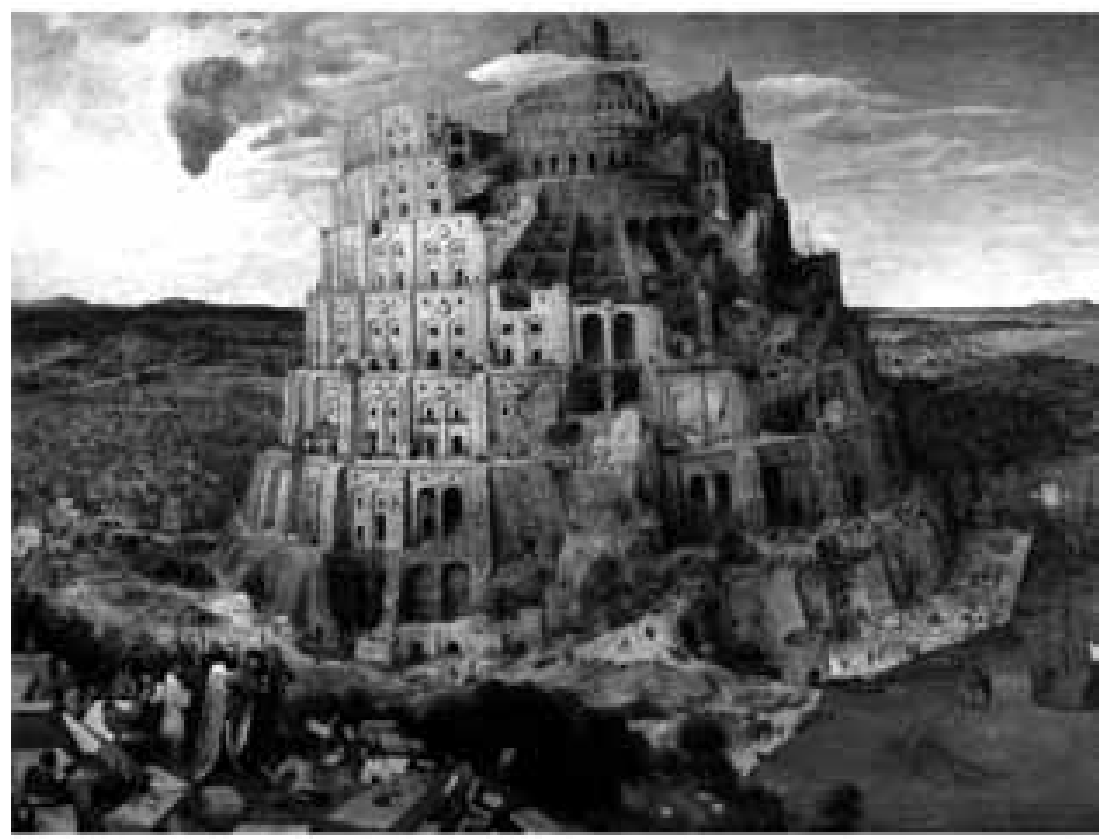




\section{Contenido}

\section{La ciudad}

A mediados del siglo XIX se sitúa el comienzo de las mayores migraciones humanas de la historia; las cifras de dicho movimiento no son exactas pero sí indican cómo el desplazamiento de poblaciones enteras se llevó cabo en una gran proporción hacia EE.UU. Las hubo de todas las formas, ya sea entre ciudades y regiones de un mismo país, el éxodo rural hacia las ciudades, la travesía de los océanos y la penetración en las zonas fronterizas. Estos movimientos de población y la industrialización van juntos, pues el desarrollo económico moderno requería reubicaciones sustanciales de poblaciones con el fin de facilitar el proceso técnico y su abaratamiento por medio de mejores y más eficientes comunicaciones, las que a su vez se justificaban según la cantidad de población a la que afectarían o, dicho de otra manera, según el mercado potencialmente disponible. Así mismo, el vacío provocado por la prohibición de la trata de esclavos que redujo dramáticamente la mano de obra, fue cubierto en cierta medida por el transporte de trabajadores asalariados. Un ejemplo de este fenómeno es el citado por Eric Hobsbawm (2001) en su ya clásica "Era del imperio" cuando recuerda cómo contingentes de trabajadores italianos apodados golondrinas, cruzaban el atlántico en ambos sentidos para recolectar cosechas en América. Estas migraciones cambiarían su carácter y reducirían su tamaño con el inicio de la Primera Guerra Mundial en 1914.

Figura 2: Calle de París, un día de lluvia

Fuente: imágenes google.com. Gustave Caillebotte

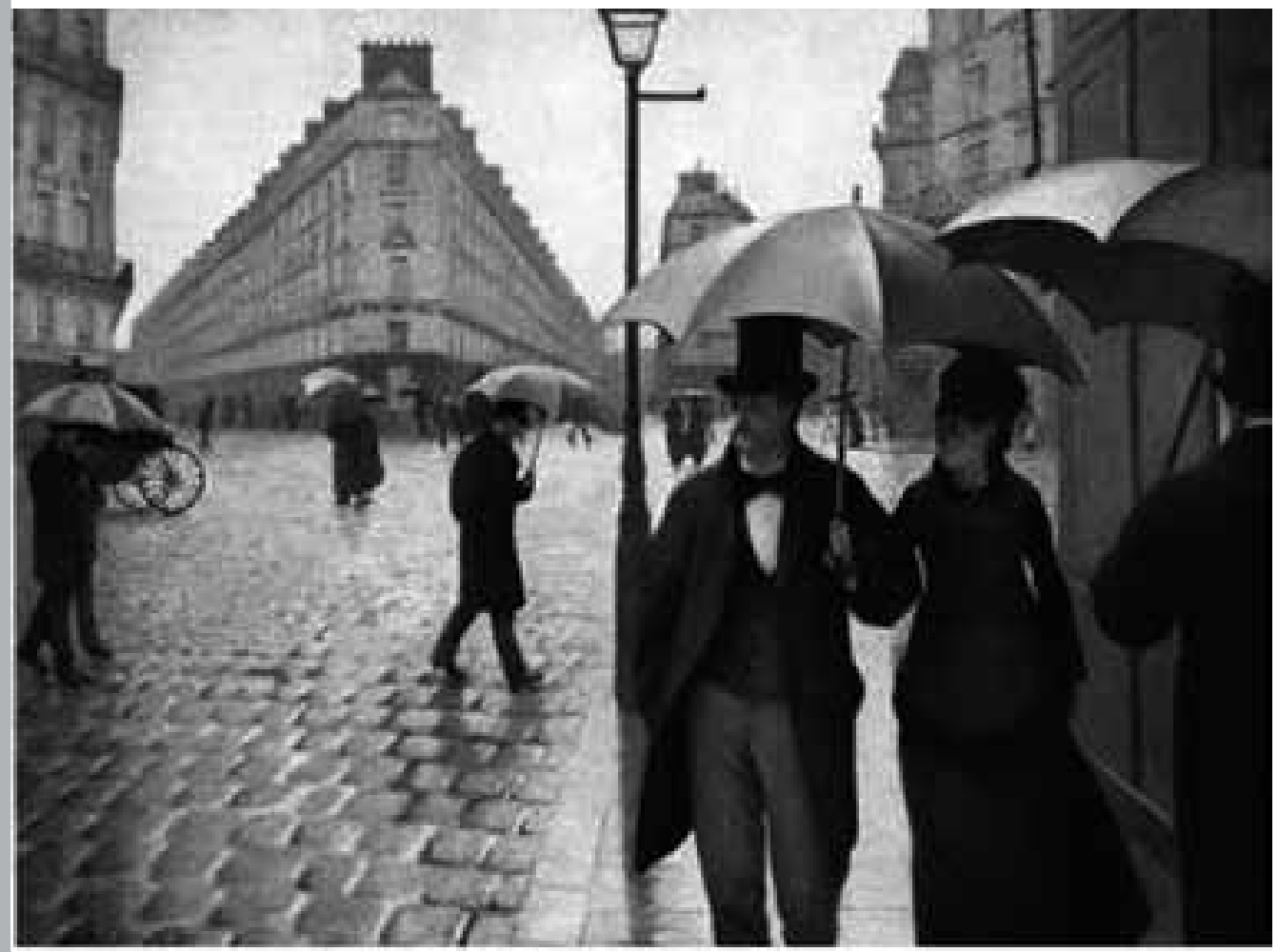


Un fenómeno característico de esas migraciones era el origen de los individuos que las componían. Como la gran mayoría de Europa era rural, así mismo lo eran los emigrantes que llegaban a las ciudades en busca de una mejor calidad de vida y, en lo posible, llenos de esperanzas. Se puede afirmar que la migración y la urbanización se desarrollan de un modo paralelo y simultáneo. Pero igualmente es la ciudad, a partir de la Revolución Francesa y posteriores oleadas industriales ocurridas entre finales del siglo XIX hasta 1913, es el escenario en que se llevarían a cabo transformaciones socioculturales, que no se percibían fácilmente y que las imágenes impresas reflejaron o al menos dejaron registradas. La ciudad estará en constante cambio pasando a veces vertiginosamente de poblado a ciudad, de ciudad a gran ciudad y finalmente a metrópoli, transformando de igual manera las formas de interacción de sus habitantes, sus maneras de transportarse, de comportarse y de ver la vida misma. Ya en el siglo XX, en su segunda década, recién terminada la Primera Guerra, se apodera del panorama europeo un nuevo espíritu de renovación.

Simultáneo con el pesimismo dadaísta se fomenta un optimismo por los tiempos venideros gracias al desarrollo que cada vez se evidenciaba en las calles, y a la nueva tecnología que hacía más fácil vivir, más cortas las distancias y más rendidor el tiempo y la vida. Es el momento en que la electricidad y sus aparatos invaden la ciudad y sus vitrinas, la luz eléctrica disuelve esa privacidad que las sombras proporcionan. Ahora desde afuera se podrá apreciar lo de adentro, hecho mucho más evidente en los grandes edificios de oficinas o apartamentos. Esta aglomeración trajo consigo la necesidad, en un primer momento, de adecuar y, posteriormente, de construir y diseñar lugares de esparcimiento públicos donde la población se divirtiera, con el consiguiente auge de los cabarets y teatros acondicionados para las necesidades que una proyección requería. La ciudad como sede de la industria y del capital industrial generó nuevas clases sociales, el mundo obrero y la burguesía, un público masivo que demandaba desde toda clase de productos de consumo hasta arte, comunicación y entretenimiento. El último tercio del siglo XIX condensó la primera expansión de la propiedad raíz de carácter urbano y a la par vino el auge de la construcción. Pero la gran ciudad moderna no es sólo la ciudad física también trajo consigo un nuevo conjunto de sensaciones.

Es evidente la polarización de la población urbana, la cual se dividió en dos grandes grupos: uno que percibía la ciudad como centro de perdición de la conciencia humana donde, con mayor intensidad, la rutina se apodera de la vida diaria y el individuo pasa a ser sólo una cifra estadística; donde las relaciones personales se ven limitadas y cohibidas por factores como las distancias, el tiempo y las dificultades para socializar con amigos y conocidos; y un segundo grupo que, por el contrario, concebía a la ciudad como el lugar donde confluye la vida, el comercio y la diversión, la cultura, el progreso y el bienestar socioeconómico para quienes, la ciudad está más allá del bien y del mal. 
La clase media del siglo XIX pensaba que la ciudad era el refugio de las actividades más valiosas para el ser humano, es decir, la industria y la cultura. La ciudad en los dos siglos anteriores al XX había sido considerada como una especie de entidad que presentaba tres formas de evaluarse a sí misma.

- La ciudad como virtud, (siglo XVIII) con el iluminismo. Como centro de la educación, las universidades, el comercio, las artes y el poder, contraria a la ignorancia, barbarie, lejanía y dificultades del campo.

- La ciudad como vicio, (siglo XIX) con el apogeo industrial y centro de las migraciones se convirtió en el lugar de ocio de los obreros; por consiguiente, surgen las aglomeraciones y la necesidad se suministrar modos de diversión a tanto ocioso. El circo, el cabaret, el cine, el prostibulo y la taberna, son los sitios más recurridos con fines de entretenimiento por parte de las masas urbanas.

- La ciudad más allá del bien y del mal, (mediados siglo XIX) percepción y actitud generada por los intelectuales, políticos e inversionistas que desarrollaban su diario quehacer sin salir de la ciudad y en dependencia total y continua de las bondades que ésta brindaba a los ciudadanos, actuando consecuentemente con la sensación de que la ciudad era el centro de la vida, donde todo lo hay y está y donde se debe aprender a convivir con ciertas limitaciones, como por ejemplo en espacios reducidos de apartamentos, pagando servicios, entre ruidos y aglomeraciones, etcétera.

Voltaire (1694-1778) a través de toda su obra afirmaba que la combinación de industria y placer generaban la civilización, ricos y pobres no debían producirse mutuamente terror sino por el contrario, debían tomar conciencia de que juntos, eran la base del progreso. Según Voltaire la nobleza civilizaba a las ciudades, elemento con el que el campo no contaba, mientras que para Adam Smith (17231790), la ciudad como fenómeno moderno industrial, civilizaba a la nobleza rural y desvanecía el señorío feudal.

En un amplio panorama, las críticas a la ciudad como foco humano podían ser de dos tipos: las arcaístas, generadas por los que proponían abandonar la gran ciudad, ya que según ellos la buena vida no se podía vivir en la ciudad; el ruido, la aglomeración, la pérdida de lo privado y el temor constante la hacían invivible. Dos: las futuristas, con la llegada de los conceptos socialistas que pretendían vigilar la burguesía, la propiedad y el capital privado en beneficio y protección de la clase obrera surgida gracias al desarrollo industrial, fenómeno típicamente urbano, que estimulaba la construcción de barrios obreros, vías y medios de transporte, acceso a la cultura y educación. 
Por otro lado, casi todos los movimientos artísticos e intelectuales de principios del siglo XX predicaban un optimismo sobre la nueva tecnología del momento, tal como las máquinas calculadoras que desde 1812 se venían desarrollando, los motores a gasolina que automáticamente evolucionaron al automóvil, los trenes, los modelos para volar, la fotografía, el cine, los telégrafos y la luz eléctrica, el gas domiciliario, los rayos $\mathrm{X}$ aplicados a la medicina, la química farmacéutica, las máquinas de guerra, el submarino, la cromolitografía y el offset, entre otros. La reproducción mecánica y en gran número de imágenes impresas resultó fundamental. Pero junto a las imágenes estaban otros entornos en donde se experimentaban las particularidades de la vida urbana; por ejemplo la taberna, que se convertiría posteriormente en el gin-palace tan típicamente británico, el music-hall, el teatro, el cinema, lugares éstos donde se moldeaban nuevos hábitos urbanos, conductas sociales y modos de convivencia. Departían en estos espacios seres llegados de diferentes regiones o ciudades. La ciudad se convirtió en el símbolo externo más llamativo del mundo industrial. Una gran ciudad, una metrópoli de más de medio millón de habitantes, no era tanto un centro industrial, como un centro de comercio, de transporte y administración, de provisión de servicios, lo que causaba una gran aglomeración de individuos.

\section{El individuo}

Es evidente que una característica de la llegada del siglo XX es la aparición de un nuevo hombre cuya vida estaba moldeada por un elemento que se había constituido en parte primordial de su cotidianidad: el factor tiempo. Es cier to que este concepto no era nada nuevo, desde siglos antes, el aprovechamiento al máximo del mismo, su correcta distribución, las horas y los momentos en el día, la implementación y desarrollo del reloj en todas sus modalidades, y la sensación de una vida sujeta a un mundo cada vez más veloz, estaban presentes en la vida diaria de los ciudadanos, pero es a comienzos del siglo XX cuando se torna en predicado constante, intenso, avasallador e imprescindible. El tiempo es oro, antigua consigna, ahora se aplicaría al diario discurrir urbano.

Según Simmel (1984), el hombre es un ser de diferencias, esto es, su conciencia es estimulada por la diferencia entre laimpresión del momento y la impresión precedente. Las impresiones persistentes, la insignificancia de sus diferencias, las regularidades habituales de su transcurso y de sus oposiciones, utilizan menos conciencia que la rápida aglomeración de imágenes cambiantes. La gran urbe produce justamente estas condiciones psicológicas, desatando en el individuo y el colectivo una profunda oposición contra la ciudad pequeña y la vida del campo que posee un ritmo más lento y regular y que deja ver más bien una imagen senso-espiritual de la vida. Así pues, la base psicológica sobre la cual se edifica la mentalidad del individuo y el colectivo urbano es el acrecimiento de la vida nerviosa, palabras textuales de Simmel, que tiene su origen en el rápido e ininterrumpido intercambio de impresiones internas y externas. 
Es justamente ese individuo que habita la gran ciudad el que comienza a manifestar el cambio, nuevos factores en su vida empiezan a ser considerados. Ese nuevo individuo es ahora un individuo apurado, se sacará el mayor provecho posible del tiempo, nada que no produzca ganancia a partir del uso provechoso del tiempo valdrá la pena, y para ello se recurrirá a la moderna tecnología, que tan eficientemente colaborará con sus nuevos inventos veloces y dinámicos. Según Simmel, el espíritu moderno se habría convertido cada vez más calculador, no sólo en cuestiones económicas sino en cantidades de tiempo.

Cuando Filippo Marineti (1876-1944) publicó su Manifiesto del Futurismo el 20 de febrero de 1909 en el periódico parisino Le Fígaro, su texto revoltoso estableció al futurismo como un movimiento renovador de todas las artes. Cito a Marineti: "Nosotros intentamos celebrar el amor al peligro, el hábito a la energía y la intrepidez". Y más adelante proclamaba: "Afirmamos que la magnificencia del mundo ha sido enriquecida por dar una nueva belleza: la belleza de la velocidad. Un carro zumbante que parece cabalgar sobre la metralla es más hermoso que la victoria de Samotracia”. El manifiesto expresaba el entusiasmo por la guerra, la época de la máquina, la velocidad y la vida moderna, y cómo el ruido y la velocidad, dos condiciones dominantes de la vida del siglo XX se expresarían en la poesía futurista. Éste era el medio que rodeaba al hombre apurado, era la vanguardia que se desarrollaba a su alrededor.

En el momento en que Marcel Duchamp (1887-1968) se unió al movimiento del Dadaísmo y se convirtió en su artista visual más prominente, era el cubismo lo que más influía en su obra. Se advierte, por ejemplo, en el análisis de planos geométricos. Pero fue el futurismo el que lo inspiró en la transmisión del tiempo y el movimiento. Para Duchamp, el arte y la vida eran procesos de probabilidad aleatoria y elección deliberada. Los actos artísticos se volvieron asuntos de decisión y selección individual. Esta filosofía de libertad absoluta permitió que Duchamp creara esculturas ya hechas como sus ruedas de bicicleta, montadas sobre un banco de madera o su famoso orinal. La obra de arte perdería su aura, ya no hay tiempo para su ejecución, surgirá el ready made, las obras ya hechas, el asunto será denominarlas obras de arte y no se requerirá ejecutarlas, ya vienen listas gracias a la moderna tecnología que se desarrolla en las metrópolis.

Los estilos que crearon los diversos movimientos artísticos durante los primeros años del siglo XX dejaron su impronta sobre el diseño coetáneo de impresos y carteles. Estos evolucionaron rápidamente del historicismo victoriano, con sus imágenes dulces y míticas, a los temas directamente urbanos como la promoción de sitios de baile y esparcimiento, además de publicitación de las figuras del momento. El ochenta por ciento de las ediciones de carteles a finales del siglo XIX y comienzos del XX eran encargadas por los empresarios de revistas musicales, compañías de teatro y opereta como también por circos de todos los tamaños y orígenes. Pero para los 
años 20 las grandes compañías de turismo y trasatlánticos, así como las de trenes y automóviles, habían desplazado a las anteriores. La revista, una publicación más ligera que un libro extenso y físicamente pesado, encontró su apogeo gracias a que, precisamente, fue concebida para hacer más placentero y amenizar el acto del viaje, y se desarrolló en plena revolución industrial debido a la diversificación y depreciación de los medios de impresión, el incremento del público lector y la gran variedad de temas que permitían especializar su contenido. Así, las revistas tuvieron empuje gracias a la cromolitografía, gran invento del periodo industrial, tanto como el mejoramiento e implementación de más y mejores vías de comunicación que favoreció su pronta distribución. El arribo del automóvil, la aviación, la nueva vida social citadina y la farándula, brindaron un amplio abanico de temas, variedades y públicos consumidores: surgieron las revistas especializadas en mecánica automotriz, electrodomésticos, deportes y farándula, culinaria, música, etcétera.

\section{El Automóvil, el hombre apurado} avanza sobre ruedas

Figura 3: Cartel hombre sobre triciclo Fuente:The poster in history. Max Gallo

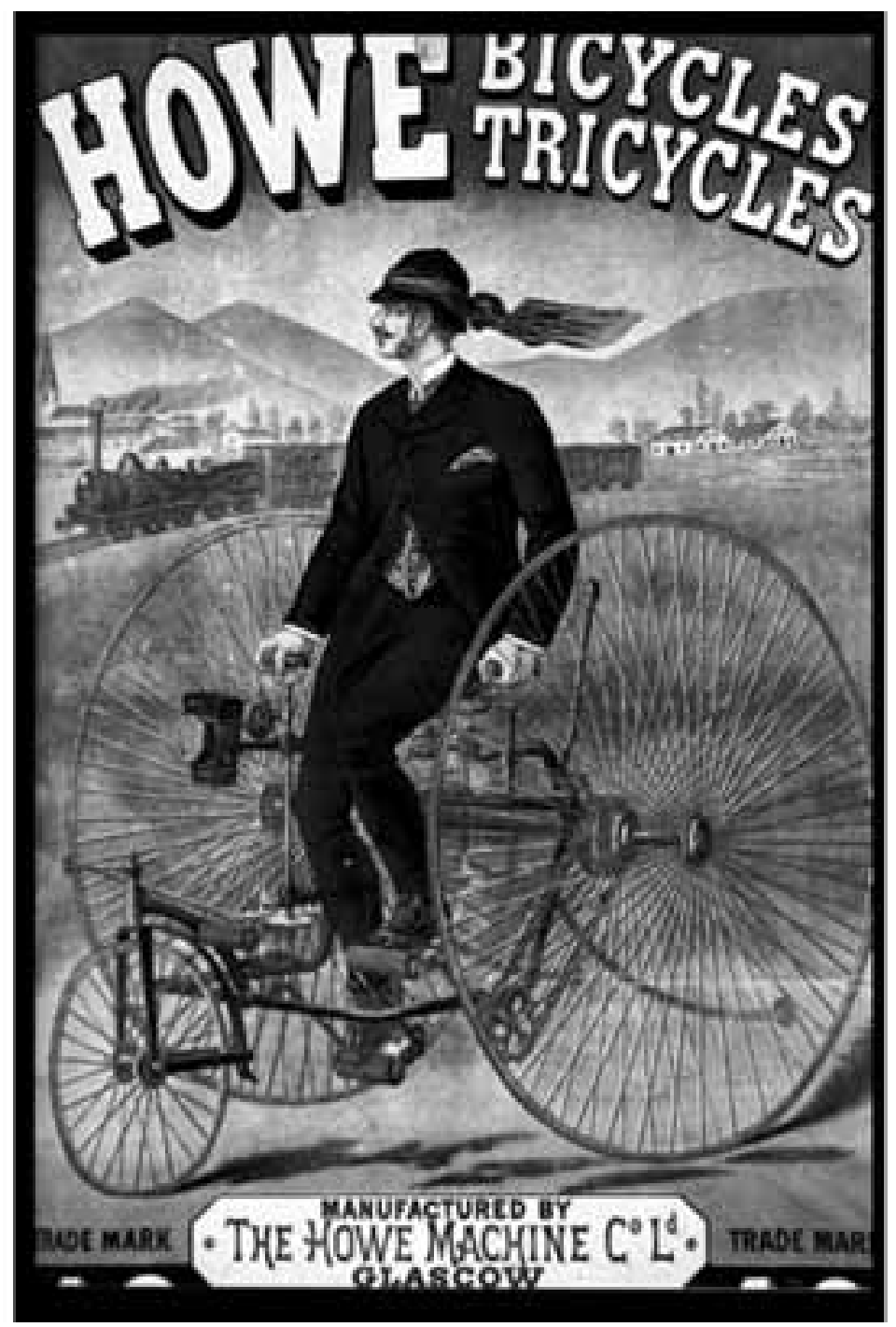


Y de esos inventos ¿cómo no destacar al más espléndido, veloz, novedoso y evolucionado automóvil? Recorrer la ciudad gracias a éste sería fácil y rápido, conocer incluso otras ciudades sería cosa de horas, las distancias se minimizaron y los peatones se divisan ahora más lentos, van a otra velocidad pasada de moda. jAhora la prioridad la tiene el auto!, para su mejor desempeño se construyen las vías, los espacios públicos y las señales de advertencia. El automóvil es la estrella y como tal se le dedican entonces las mejores carátulas, se editan revistas sólo por él y la moda cambiará, ya no dictada desde la gran París sino desde las revistas de autos. Para los conductores los vestidos serán diseñados y pensados para favorecer su comodidad durante la conducción. La ciudad comenzó a desplazar las imágenes pastorales de Monet y Renoir, la imagen prototipo de la pintura no fue más el paisaje sino la gran metrópoli, y dentro del nuevo paisaje, ninguna pintura convencional podría representar a la nueva experiencia pública de finales del siglo XIX y comienzos del $\mathrm{XX}$, como era el viajar más rápido y lejos sobre una máquina con ruedas.

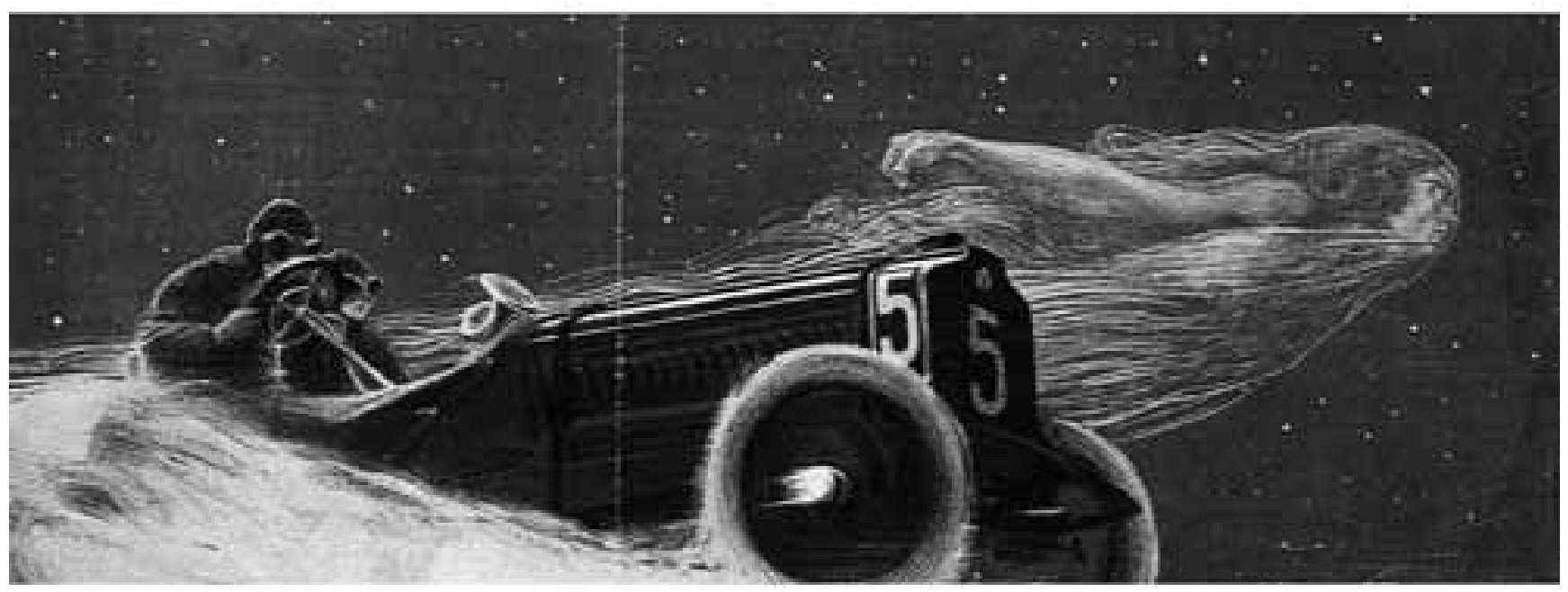

Figura 4: Homenaje al automóvil

Fuente:The poster in history. Max Gallo

El auto no era la única creación en apogeo, de igual manera estaban el tren y los grandes barcos trasatlánticos. La máquina veloz se toma por asalto todas las propagandas y el impreso lo refleja en sus ilustraciones. Estas maravillas industriales no venían solas, con ellas estaba implícita la velocidad que planteaba un inconveniente nuevo: la lectura de cualquier anuncio debía hacerse a mayor velocidad, por lo cual su comprensión sería más difícil y a su vez el diseño requeriría un estudio minucioso en cuanto a síntesis del mensaje, tipografía clara y contundente y resumen de color atractivo. 
Así como los conductores se habían acelerado, el fenómeno experimentaba en contrapartida una reacción igualmente acelerada de los peatones, éste también tenía horarios y citas por cumplir, detenerse a leer un cartel sólo se llevaría a cabo si éste era lo suficientemente atractivo para captar su atención. De allí parten las teorías que consideraban (aún hoy) al cartel como un golpe visual que se dirigía al transeúnte y que debía ser tan contundente como para dejarle el mensaje. Es entonces cuando emergen los aportes técnicos y de diseño de Bemhard (18831972), diseñador autodidacta, quien sustituyó el naturalismo en la comunicación gráfica por un lenguaje de forma y señal más avanzado, empleando formas de colores sin brillo, el nombre e imagen del producto. Recurriría a este método innumerables veces durante las décadas siguientes, siempre con énfasis en reducción con formas minimalistas y simples.

A las largas distancias se contraponía ahora el encogimiento del tiempo y los momentos y con ellos también los individuos. "Qué estrechas se habían vuelto las mujeres últimamente", es una cita textual a la que recurre Clair para recordarnos cómo los peinados, sombreros y atuendos se habían reducido en tamaño y apariencia por manifiestas razones, pues era muy complicado viajar en auto descubierto luciendo grandes sombreros de plumas y vestidos que llegaban a los pies, dejando entre ver un nuevo individuo de carácter andrógino, es decir, un ser humano de aspecto absolutamente ambiguo en determinación sexual externa.

Figura 5: portada revista Motor, 1923

Fuente: Great magazine covers. Patricia Frantz Kery

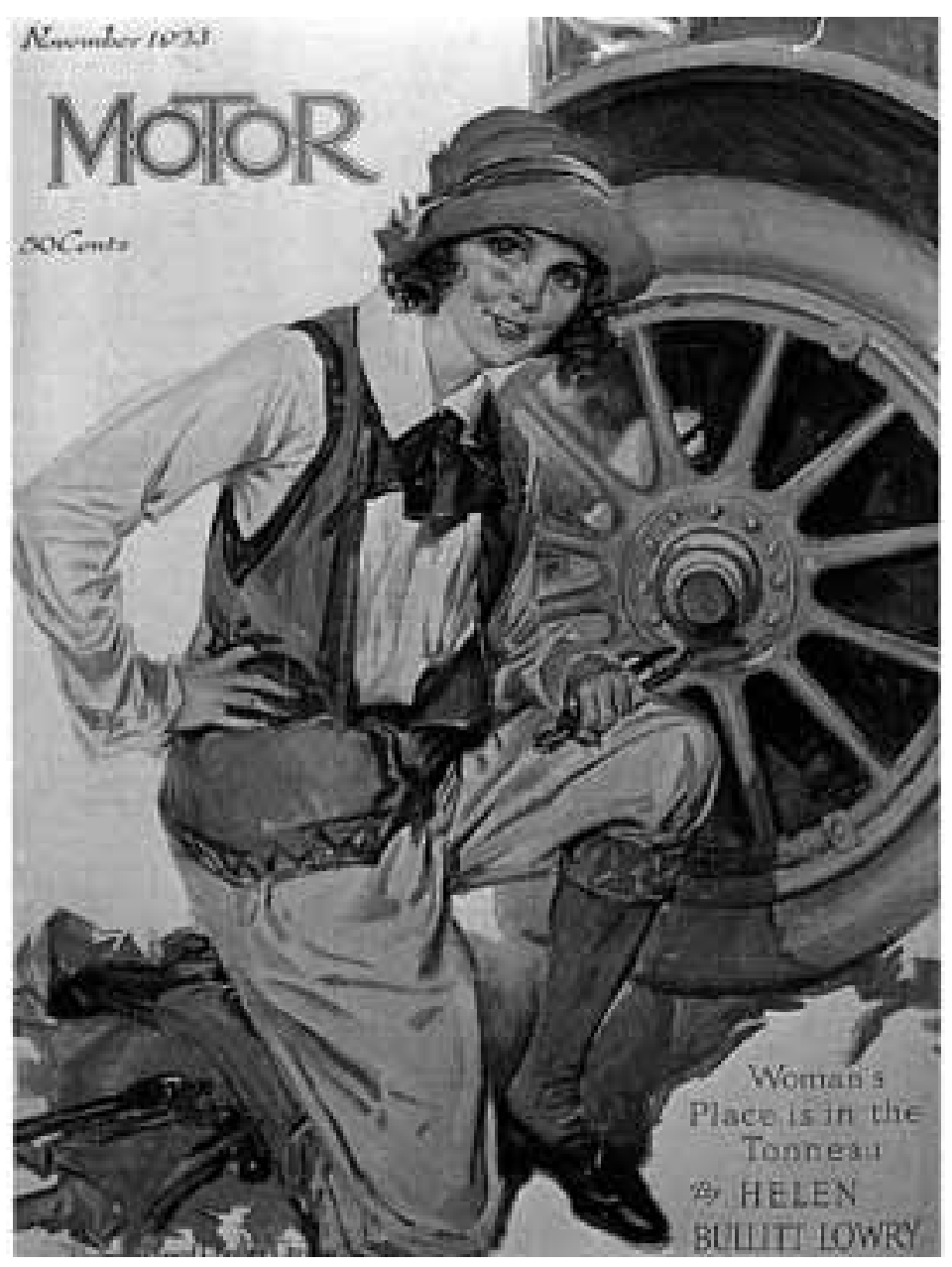


El turismo y las vacaciones se convirtieron en la modalidad favorita de placer durante la revolución industrial, ya fueran las vacaciones de verano para la burguesía o las excursiones motorizadas para las grandes masas de proletarios y obreros que se habían aglutinado en las ciudades como resultado de la implementación del vapor al transporte. Se hicieron factibles los viajes regulares para gran número de pasajeros. El turismo y las vacaciones, son temas recurrentes para los diseñadores de la gráfica del momento. Las compañías que cubrían las rutas a través del atlántico desplegaron toda una campaña publicitaria que se llevó a cabo por todos los medios publicitarios, allí el impreso desempeñó un papel preponderante. Se resaltan los carteles de Cassandre, quien desde los catorce años había emigrado precisamente a París desde su natal Ucrania. Estudió en la Ecole des Beaux Arts. De 1923 hasta 1936 y revitalizó el arte publicitario francés por medio de famosos carteles.

Figura 6: Cartel de trasatlántico

Fuente: Historia del diseño gráfico. Philip Meggs.

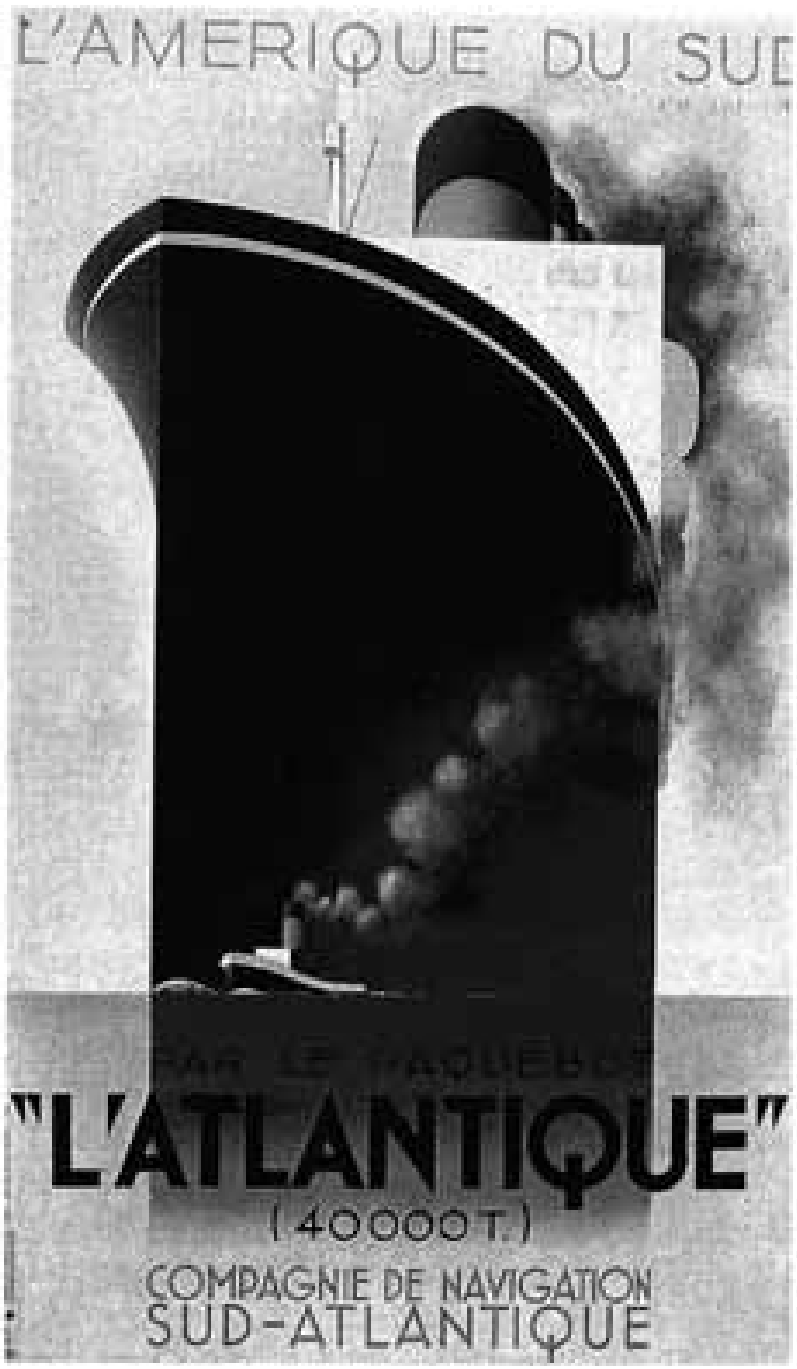

Los diseños sencillos y audaces de Cassandre enfatizaban la dimensionalidad compuestos por planos amplios simplificados de color. Muchas de sus mejores piezas fueron para empresas ferroviarias y líneas marítimas. 


\section{La Mujer}

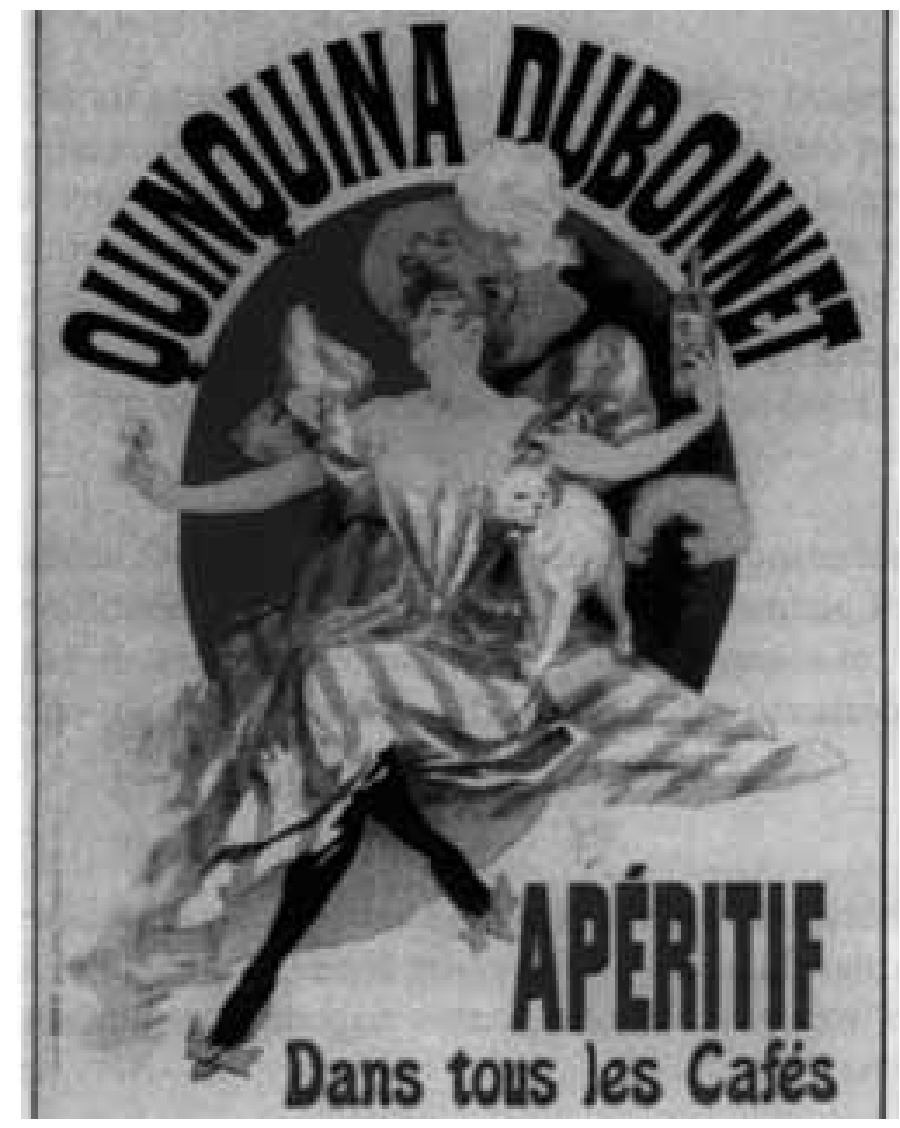

Figura 7: Cartel para Dubonnet, 1898

Fuente: imágenes google.com.

En 1846, el comerciante de vinos francés Joseph Dubonnet decidió entrar al negocio con un producto propio. Como las bebidas medicinales estaban en boga, escogió la quinina y para evitar su sabor agrio la mezcló con vino dulce de Grecia. El resultado pronto ganó aceptación y popularidad. Para finales del siglo la compañía producía tres millones de botellas por año y se exportaban a varios países. El cartel para el aperitivo Dubonnet que mostraba a una joven mujer disfrutando de beber un licor fue realizado por Jules Chéret (1836-1932) pionero del cartel moderno francés. Lo realizó en 1898, y contrató como modelo profesional Lise Fleuron, una bailarina del conocido show de música y baile ofrecidos en el "Theatre des ambas sadeurs". El cartel se hizo tan popular que la modelo pudo promocionarse a sí misma como la chica Dubonnet.

Ella luce espléndida en su vestido de rombos aguamarinas y beige, escote amplio, cintura entallada y sombrero aguamarina que enmarca su cabellera rojiza. Sentada frente a una luna roja, cruza sus piernas enfundadas en medias negras. Sus zapatos del mismo color se adornan con grandes y coquetos moños. Su cara de lado e inclinada ligeramente hacia atrás hace que la mirada del espectador descanse en su pecho blanco, que se hace más aparente debido a la posición de brazos extendidos a sus lados. En una mano alza una botella, en la otra sostiene una copa. Sin duda el cartel Quinina Dubonnet es un antecedente del posterior bombardeo de anuncios donde lo que vende es la imagen femenina. En la Francia del siglo XIX la mujer fue descubierta como tema y como mercado. 
La manufactura de vestidos que cobró fuerza con la industrialización y el giro de la economía del campo a la ciudad, vio en la mujer sus posibilidades de consumo. En la década de 1890 el cartel alcanzó su mayor apogeo como parte del proyecto de urbanismo y transformación de París. Por aquel entonces, en las galerías se mezclaban imágenes de madre nodriza e hija con las estrellas de cabaret, bailarinas y prostitutas, así como de trabajadoras en el campo y la ciudad.

Ser una mujer trabajadora a mediados del siglo XIX, automáticamente hacía sospechosa su reputación. Tales códigos de género fueron frenos poderosos hasta entonces a la capacidad de las mujeres para moverse en el mundo. Como resultado, pocas se convirtieron en figuras públicas prominentes. Artistas como Rosa Bonheur, Cassatt y Berthe Morisot, son excepciones que sólo confirman la regla. Esta anécdota no sería evidente si el cartel no hubiera plasmado en su imagen ese cambio en la percepción y concepción del rol de la mujer en una sociedad burguesa que se encontraba en pleno cambio y renovación espiritual a finales del siglo XIX y comienzos del XX. Como este cartel son innumerables los impresos publicados con el mismo recurso iconográfico, la mujer, como símbolo de transformaciones que la nueva época y sociedad burguesa experimentaban en su seno y que los artistas sensible e inteligentemente plasmaban en impresos.

La época victoriana fue una etapa de fuertes creencias religiosas y morales, convenciones sociales y optimismo. "Dios está en su cielo, todo está bien con el mundo", fue un lema popular del momento. El largo reinado de Victoria (1819-1901) quien se convirtió en regente del Reino Unido de la Gran Bretaña e Irlanda en 1837, abarcó dos tercios del siglo XIX. Desde la década de 1850 la palabra victoriana comenzó a ser utilizada para expresar una conciencia del espíritu, cultura y valores morales de la época industrial. Los diseños gráficos capturaron y proyectaron los valores de la época. El sentimentalismo, la nostalgia y los principios de la belleza idealizada fueron expresados por medio de imágenes impresas de niños, doncellas, cachorritos y flores. Los valores tradicionales del hogar, la religión y el patriotismo fueron simbolizados con dulzura y piedad.
¿Qué era eso tan evidente que se manifestaba por medio de las imágenes impresas? Es el derecho ahora reclamado por la mujer a gozar de los placeres que el mundo brindaba y que hasta entonces se habían reservado para el hombre. Quedaba atrás la mujer del periodo victoriano, recatada, reservada e íntima, cuya interioridad espiritual y conceptual no podía exhibirse en público y a la que se trataba como propiedad privada del hombre.

Tomando las observaciones de Hobsbawn (2001) es fácil detallar cómo la burguesía de mediados de la época victoriana ostentaba una gran variedad de pesados ropajes, dejando pocas zonas del cuerpo visibles, incluso en los climas tropicales. Así mismo, en la vida pública la respetabilidad era incompatible con la diversión, la civilización se asentaba sobre la represión del instinto. Era tan manifiesto, que Freud tomó este asunto como la piedra angular de sus teorías.

Siendo así es fácil deducir el mensaje tan opuesto que este cartel manifestaba al público lector, a ese individuo apurado y acosado que habitaba la gran ciudad y más directamente a la mujer, la vida tiene más cosas y otras que ayudan a disfrutar la vida, recurrir a ellas harían de la mujer un ser más feliz, espontáneo y alegre como Madame Dubonnet. La mujer bebiendo como símbolo público de alegría daba visualmente el golpe de gracia a la mojigatería victoriana. ¿Y qué decir del atuendo? La joven del cartel luce un cómodo vestido escotado, colores estridentes y su rostro anticipa la llegada del placer. La nueva vida, el nuevo siglo y sobre todo la vida en la ciudad serían diferentes. ¡ Viva la ciudad! 
La importancia de las artes gráficas en el proceso por medio del cual el hombre apurado y acosado que habita la gran ciudad se percata de los cambios sociales y espirituales de la época en la que se encuentra, no se puede menospreciar. La transición de las gráficas victorianas al estilo art nouveau fue gradual. Dos artistas gráficos que trabajaban en París, Jules Chéret (1836-1933) y Eugéne Grasset (18411917), desempeñaron funciones importantes en la transición. En 1881 una nueva ley francesa respecto de la libertad de impresión, levantó muchas restricciones de la censura y permitió la colocación de carteles en todas las partes excepto en las iglesias, urnas electorales y áreas designadas para las notificaciones oficiales. Esta nueva ley trajo consigo una industria floreciente de carteles, diseñadores, impresores y pegacarteles. Las calles se convirtieron en galerías de arte para la nación, ya que aún el trabajador más pobre pudo apreciar la transformación del medio ambiente engalanado por imágenes y colores.

Jules Chéret, el creador y diseñador de dicho cartel también merece destacarse. Durante la década de 1870, Chéret evolucionó y se alejó de la complejidad victoriana, simplificando sus diseños e incrementando la escala de sus figuras principales y rotulaciones. Por el año 1884 algunos carteles de Chéret fueron producidos en tamaños hasta de dos metros de altura. Las imágenes se imprimían en secciones, que después los pegacarteles unían sobre la pared. Los tirajes de prensa anuales de sus diseños fueron de casi 200.000 copias. Su estilo llegó a tanta popularidad que sus modelos y las imágenes de éstas se denominaron "las cherettes"; fueron arquetipos no sólo por la presentación idealizada de la mujer en forma masiva sino por una generación de mujeres francesas que adoptaron su forma de vestir y aparente estilo de vida. Lo apodaron padre de la liberación femenina.

Hasta entonces las opciones para las mujeres estaban limitadas a los estereotipos de la dama decente en el salón de recepciones y la ramera en el burdel, pero las cherettes rompieron esta dicotomía. Ni puritanas ni prostitutas, estas mujeres felices, seguras de sí mismas, disfrutaban la vida al máximo usando vestidos de escote bajo, bailando, bebiendo vino y fumando en público.

Otro caso que amerita ser destacado en este escrito es el modelo de la mujer representada e ilustrada por el artista de origen checo Alphonse Mucha. Desde 1895 el Art Nouveau encontró su manifestación más amplia en el trabajo de Mucha. Su tema dominante fue una figura central femenina rodeada por formas estilizadas derivadas de flores y plantas. Fue tan persuasivo su trabajo que por el año 1900 se alternaba el término Le Style Mucha con el de Art Nouveau. 
Las mujeres ilustradas por Mucha proyectaban un sentido arquetípico de irrealidad. Exóticas, sensuales y sin embargo semejantes a doncellas, no expresaban una edad, nacionalidad o periodo histórico específicos. Sus estilizados modelos de peinados se convirtieron en un distintivo de la época, a pesar de sus detractores que los desmerecían comparándolos con peinados de fideos y espagueti. El volumen total de la producción de Mucha fue sorprendente. Pero lo que atañe es el momento que estas mujeres reflejan, no sólo con su atuendo abierto y exponente sino con sus actitudes. Fumar ya no será un acto prohibido ni mal visto, la mujer decidirá sobre sus placeres, fumará o gozará del aire libre y paseará en bicicleta, disfrutará de la velocidad que el mundo moderno brinda con sus estupendas máquinas veloces.

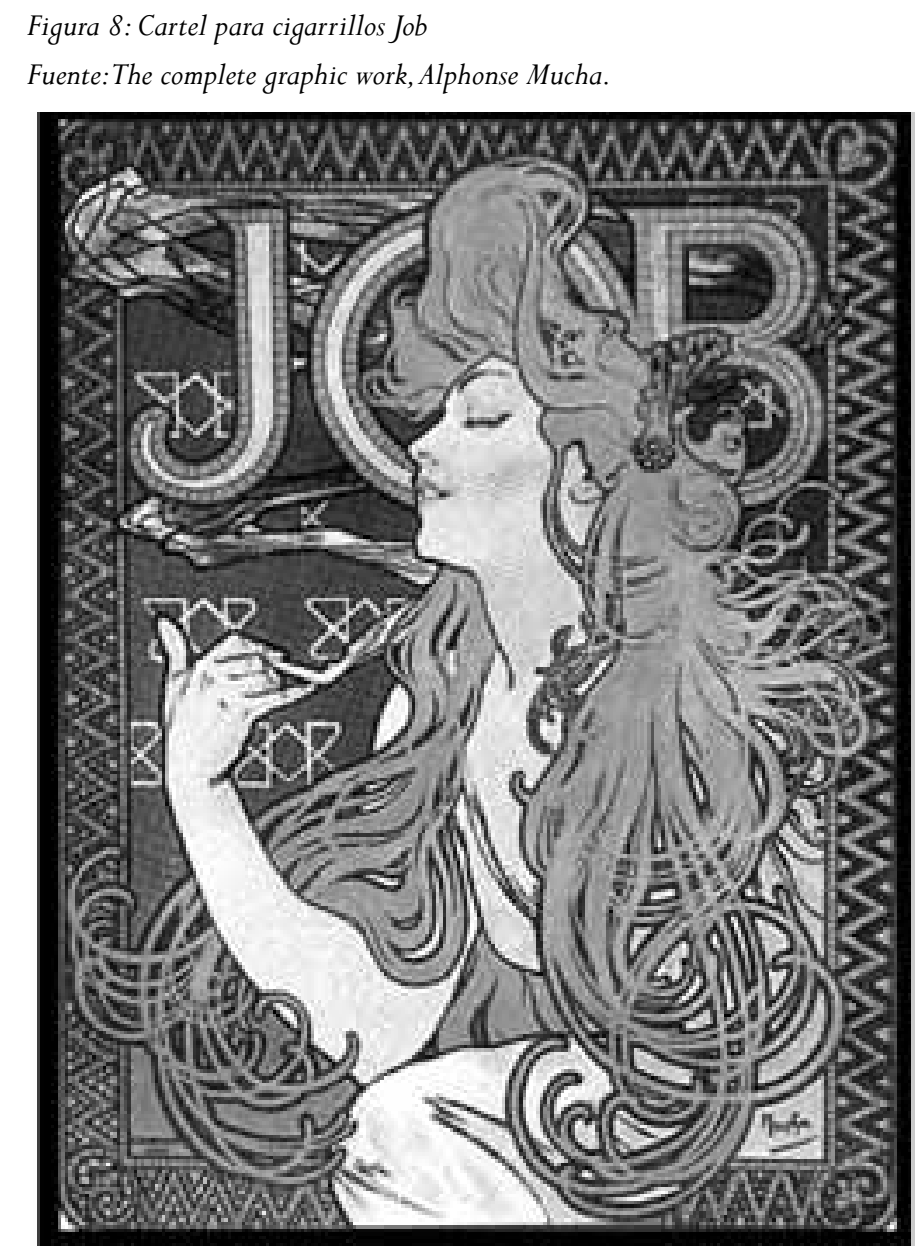

\section{Limpio que te quiero limpio}

"El hombre moderno nace en un hospital y muere en un hospital, en consecuencia debería vivir en un lugar similar a un hospital" (MUSIL: 1988, p.16-17). La implementación del alumbrado público en las grandes ciudades europeas produjo un extraño sentimiento de asepsia que comenzó a apoderarse de los ciudadanos. La veladora fue desplazada por la lámpara, la moderna persiana pasó a reemplazar a la vieja y empolvada cortina que no permitía ver hacia adentro y que generaba demasiadas sombras al interior de las viviendas. Con la llegada de la luz eléctrica el panorama cambió, el interior privado y desconocido se hizo visible en las noches, los ventanales grandes de los nuevos edificios y oficinas permitían al transeúnte contemplar el interior de los establecimientos, restaurantes y oficinas, la privacidad cedió ante lo público. Simultáneamente, los rostros de las mujeres comenzaron a verse más pálidos, todos iguales bajo las luces de las lámparas eléctricas, sin sombras ni volúmenes para distinguir, una especie de emparejamiento de las facciones que las convertía en especie de maniquíes sin color, enmarcadas por las creaciones de la moda vigente y similar para todas. 
Rápidamente se había dejado atrás el sombrío expresionismo para rendir culto al vidrio, la pared transparente y la iluminación total, donde los cuerpos parecían perder su contorno y definición. Efectos similares produjo la instalación de tuberías para la distribución casera de gas natural, las cocinas dejaron de someterse a la iluminación que proporcionaba la estufa de carbón y el consecuente hollín que todo lo ensuciaba. La nueva tecnología todo lo abarcaba y lo iba limpiando metódicamente. Nada podía ser más moderno que una madre diera a luz en un cuarto pleno de luz blanca sin olores ni sombras. Con solo abrir la llave surgía el agua caliente. La lavadora con caldera para calentar el agua hizo su aparición, los detergentes y toda clase de productos para la higiene y la salud fueron exhibidos y ofrecidos por medio de abundantes carteles que empapelaron las calles, revistas con hermosas y atractivas carátulas e innumerables recursos publicitarios.

Figura 9: Imagen publicitaria

Fuente: Los carteles: su historia y su lenguaje. John Barnicoat

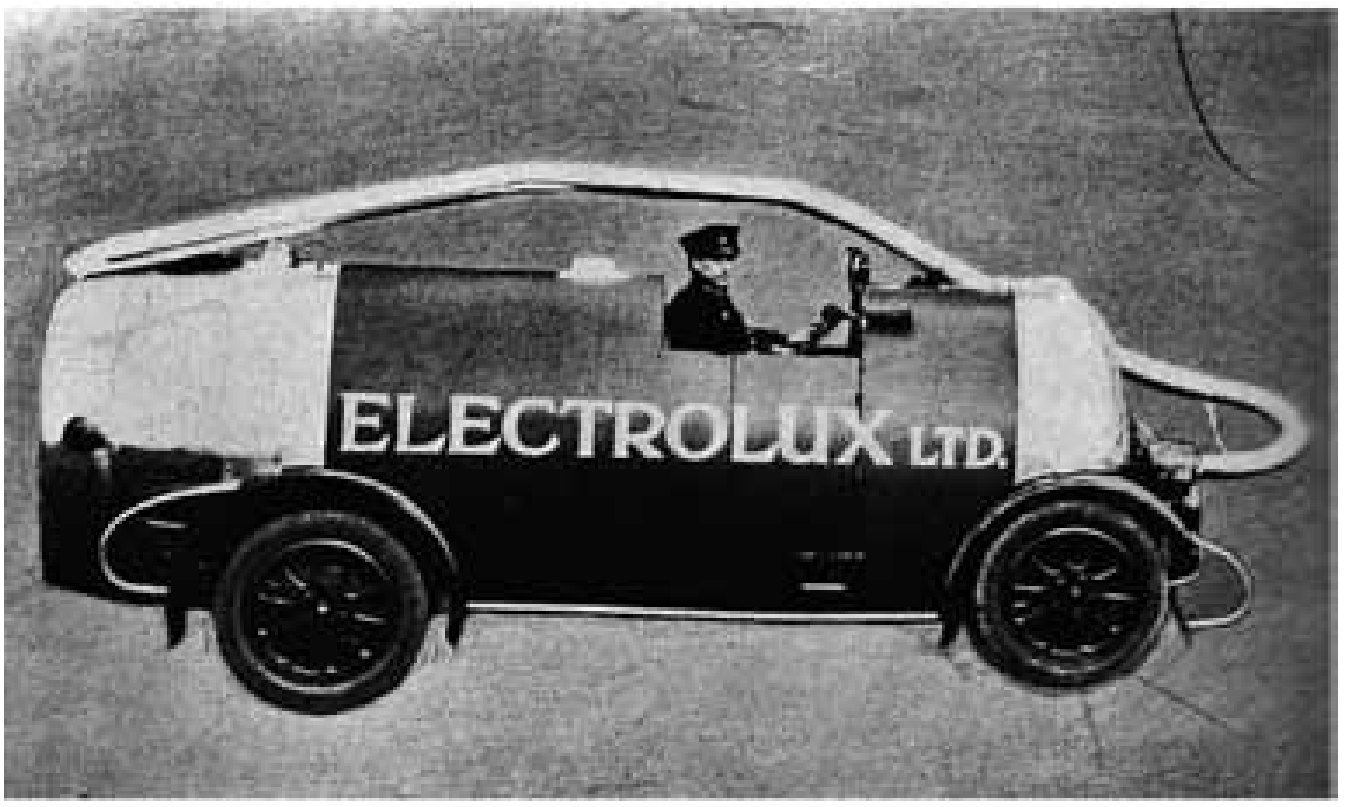

La ciudad, los edificios, oficinas, apartamentos inclusive las casas, comenzaron a verse y percibirse como si fueran asépticos e iluminados quirófanos; y la luz, el agua caliente, el brillo, se pusieron de moda como símbolo de una época nueva, rápida y moderna que hacía olvidar la mugre, el barro y la sangre de la guerra recién pasada.

\section{Los Robots}

El cambio no podía ser gratuito, algo se debía pagar por el derecho a utilizar libremente la ciudad, la novedosa tecnología y sus derivados limpios e iluminados: el precio era la desaparición del alma, del espíritu del individuo y su consiguiente esclavización a las máquinas. Se convertiría el hombre en un robot diseñado para el trabajo, no pensaría y sólo ejecutaría instrucciones, trataría de emular a la máquina que tan eficiente se mostraba, vender el alma en pos del rendimiento sería su condena. La ambigüedad entre rasgos femeninos y masculinos, generalizó una imagen de androides claros, limpios, futuristas, muy apropiado para la promoción de sombreros, peinados y 
aditamentos para conductores. Se generalizó para los conductores de autos un gorrito-casco, concebido dentro de la estética Déco, que hacía indeterminable el sexo del conductor. Simultáneamente los peinados femeninos se redujeron a la expresión a lo garçon, peinado que fijado con gomina permanecía quieto a pesar del impacto del viento. La mujer comenzó a utilizar pantalón con el fin de conducir cómodamente. Recordando el cine generado por Hollywood en la época, se nota fácilmente ese look en muchas actrices y la colección de objetos que el estilo Art Déco creó para el ciudadano, la ciudad y la vida citadina. Tampoco es gratuita la concepción de películas como Metrópolis, en la cual el protagonista cambia su alma con un robot manipulado por el dueño de la gran industria.

Figura 10:The spirit of our time - Raoul Hausmann, 1921

Fuente: The shock of the new, 1981

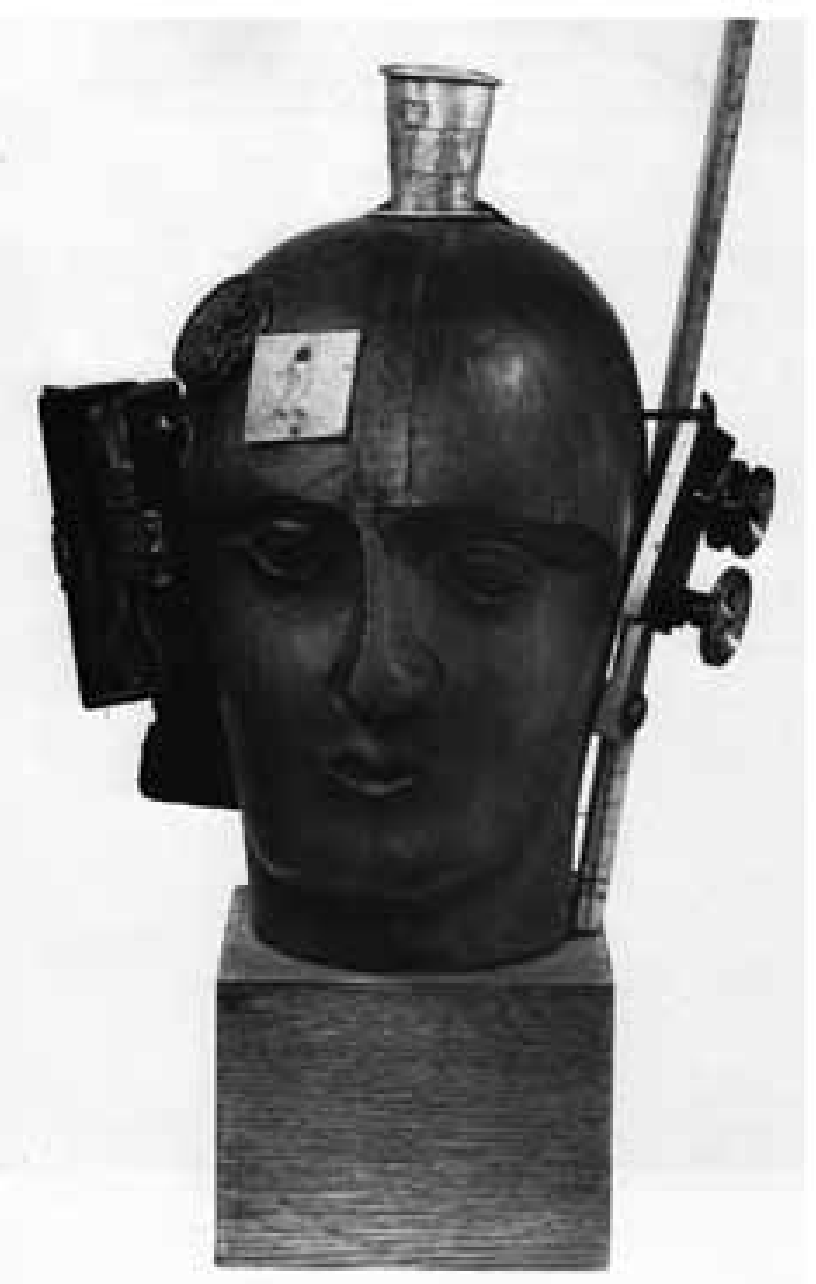

\section{Conclusión}

Si se mira la historia de la ciudad desde el punto de vista de su crecimiento arquitectónico, poblacional y sociocultural, es fácil observar cómo desde finales del siglo XIX y comienzos del XX se fueron presentando una serie de cambios vertiginosos en su composición, densidad y población, no sólo en cantidad y forma, sino especialmente en el estado anímico de la gran masa que habitaba estas grandes urbes, en los individuos que las componían y en sus formas de interactuar. 
Todos estos cambios ocurrían subrepticiamente en el interior de la masa amorfa, mezcla de arquitectura e individuos, pero había un elemento gráfico que afortunadamente dejó su huella en las paredes, y que a todo color narraba los cambios que se producían; este elemento no era otro que el impreso ilustrado. Cumplió su labor en forma eficiente, describiendo cómo la ciudad reunía a sus habitantes en lugares de esparcimiento, cómo el ser humano pasaba a ser un ser apurado por las circunstancias y por el reloj, cómo la maquina moderna y veloz había llegado para quedarse, cómo los medios para viajar y los hábitos de hacer turismo cambiaron y muy especialmente, cómo la mujer adoptaba una nueva actitud frente a la época que nacía, cómo sus gustos y forma de ver la vida y el mundo y por qué no decir a la misma ciudad, habían sufrido transformaciones radicales, marcando una amplia diferencia entre la mujer antigua del mundo victoriano y la moderna chica al estilo Chéret.

El mismo impreso sufría una serie de cambios que reflejaban el mundo que lo rodeaba y producía. Pasó de mostrar la época victoriana con todo su argumento de dulzura y mojigatería a ilustrar una nueva época donde la máquina veloz era su mayor orgullo, requiriendo un nuevo lenguaje claro y conciso para comunicar su mensaje.

No cabe duda, la imagen impresa cumple un papel importantísimo como fuente para el estudioso de una época, constituyéndose en archivo que permite ver cómo pensaba y se expresaba toda una sociedad en una época, sus estilos artísticos y los públicos a los que estaban dirigidos; todo esto sin sacrificar excelente diseño y gusto estético.

\section{Bibliografía}

Barnicoat, John. (1995). Los carteles: su historia y su lenguaje. Barcelona, Gustavo Gilli.

Clair, Jean. (1988). Red october, Black october. The 1920 age of the metrópolis. Montreal, Museum of fine arts.

Frantz Kery, Patricia. (1984). Great magazine covers. Abbeville press publishers. New York.

Gallo, Max. (1974). The poster in history. EE. UU., New American Library.

Hobsbawn, Eric. (2001). La era del imperio: 1875-1914. Barcelona, Crítica.

Meggs, Philip. (1998). A History of Gráphic Desing. México, Mçgraw Hill.

Mucha, Alphonse. (1980). The complete graphic work, New York, Armory Books

Musil, Robert. (1988). The man without qualities. Londres, London Picador.

Sennett, Richard. (1978). El Declive del Hombre Público. Barcelona, Península.

Simmel, Georg. (1984). El individuo y la libertad. Barcelona, Península.

Zátonvi, Marta. (1998). Aportes a la Estética. Desde el arte y la ciencia del siglo XX. Buenos Aires, La Marca.

Con la colaboración de Luz Alcira Silva Farfán, Coinvestigadora, grupo de investigación Estudios de la Imagen

Grupo de Investigación: Estudios de la Imagen

Línea: Teoría e historia del Diseño Gráfico

Documento de reflexión no derivado de investigación

pedro.duque@utadeo.edu.co

2427060, extensiones 1645 